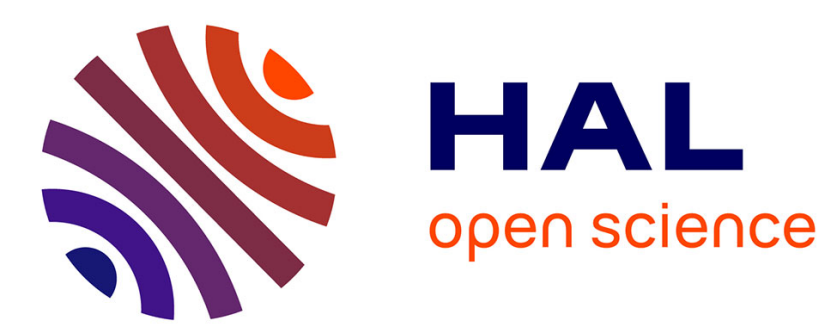

\title{
Behaviour of Li and its isotopes during metasomatism of French Massif central lherzolites.
}

\author{
Christiane Wagner, Etienne Deloule
}

\section{To cite this version:}

Christiane Wagner, Etienne Deloule. Behaviour of $\mathrm{Li}$ and its isotopes during metasomatism of French Massif central lherzolites.. Geochimica et Cosmochimica Acta, 2007, 71, pp.4279-4296. 10.1016/j.gca.2007.06.010 . hal-00672401

\section{HAL Id: hal-00672401 \\ https://hal.sorbonne-universite.fr/hal-00672401}

Submitted on 20 Feb 2013

HAL is a multi-disciplinary open access archive for the deposit and dissemination of scientific research documents, whether they are published or not. The documents may come from teaching and research institutions in France or abroad, or from public or private research centers.
L'archive ouverte pluridisciplinaire HAL, est destinée au dépôt et à la diffusion de documents scientifiques de niveau recherche, publiés ou non, émanant des établissements d'enseignement et de recherche français ou étrangers, des laboratoires publics ou privés. 


\title{
Behaviour of Li and its isotopes during metasomatism of French Massif Central lherzolites
}

\author{
Christiane Wagner ${ }^{\mathrm{a}, *}$, Etienne Deloule ${ }^{\mathrm{b}}$ \\ a Laboratoire PMMP, Université Pierre et Marie Curie, CNRS-UMR 7160, 4 Place Jussieu, 75252 Paris cedex 05, France \\ b CRPG-CNRS UPR 2300, 15 Rue Notre-Dame-des Pauvres, 54501 Vandoeuvre-lès-Nancy, France
}

Received 10 July 2006; accepted in revised form 11 June 2007; available online 23 June 2007

\begin{abstract}
Li behaviour and distribution in the mantle were investigated by ion microprobe in situ measurements on co-existing olivine (ol), orthopyroxene (opx), clinopyroxene (cpx) and amphibole (amp) in xenoliths from the French Massif Central. The fertile spinel lherzolites of this study record increasing degrees of mantle metasomatism, from unmetasomatised anhydrous samples through cryptically metasomatised samples to highly metasomatised amphibole-rich samples. In anhydrous lherzolites, $\mathrm{Li}$ is preferentially incorporated into olivine (1.1-1.4 ppm, average values) compared to pyroxenes $(0.2-0.9 \mathrm{ppm})$. The hydrous samples clearly show enrichment of Li in ol (1.5-5.0 ppm), opx (1.1-2.4 ppm) and cpx (2.4-5.4 ppm), while amphibole incorporates less $\mathrm{Li}$ than the co-existing phases $(0.8-1.3 \mathrm{ppm})$. Average $\delta^{7} \mathrm{Li}$ values range from +7.6 to $+14.5 \%$ in $\mathrm{ol}$, from 5.1 to $+13.7 \%$ in opx and from 8.8 to $+10.3 \%$ in cpx from the anhydrous lherzolites. A layered peridotite sample (Sdi) shows higher Li content in all phases, with lighter isotopic composition in opx and cpx $\left(-0.6\right.$ and $-2 \%$ average $\delta^{7} \mathrm{Li}$ values, respectively). In the hydrous lherzolites average $\delta^{7} \mathrm{Li}$ values both overlap and extend beyond these ranges in ol (up to $17.5 \%$ ) and in opx (up to $22.9 \%$ o), and vary widely in cpx $\left(-2.7\right.$ to $+9.7 \%$ ). Low $\delta^{7}$ Li values are observed in some opx $(-10.4 \%$ ) and cpx $(-13 \%$ ) from sample Sdi, and in cpx from three hydrous samples (from -9.7 to $-5.3 \%$ ). The different anhydrous phases from the hydrous samples show large intra-grain variations in Li isotopic ratios (e.g., up to $18 \%$ o) compared to the same phases from the anhydrous samples (mostly less than 6\%o), excepting sample Sdi which has up to $20.4 \%$ variation in cpx. Similar to the anhydrous silicates, amphiboles show a wide variation of $\delta^{7} \mathrm{Li}$ values on the intra-grain scale $(2-27 \%$ o). These variations are interpreted to result from fractionation processes during metasomatism by a silicate melt undergoing compositional changes as it percolates through and reacts with the peridotite phases. Thus Li abundances and isotopic in situ measurements are useful for tracing metasomatic processes but the heterogeneities observed in the samples preclude any identification of a specific mantle source by its Li signature.

(C) 2007 Elsevier Ltd. All rights reserved.
\end{abstract}

\section{INTRODUCTION}

In the last few years light elements, in particular lithium, have been increasingly used to study global-scale processes. $\mathrm{Li}$ is an alkali metal that is incorporated in mantle minerals at the ppm level (Seitz and Woodland, 2000; Kaliwoda and Altherr, 2003; Seitz et al., 2003; Ottolini et al., 2004; Woodland et al., 2004) and is moderately incompatible during

\footnotetext{
* Corresponding author. Fax: +33144273911.

E-mail addresses: cw@ccr.jussieu.fr (C. Wagner), deloule@ crpg.cnrs-nancy.fr (E. Deloule).
}

magmatic processes such as partial melting or fractional crystallization (Ryan and Langmuir, 1987). In addition, $\mathrm{Li}$ is highly mobile in fluids and has recently been used to trace fluid-related processes such as sea floor alteration, metamorphism and/or metasomatism in convergent margins and metasomatism in the mantle (Brenan et al., 1998a; Decitre et al., 2001; Paquin and Altherr, 2002; Woodland et al., 2002). Li concentrations in basalts vary between 4 and $10 \mathrm{ppm}$, whereas the bulk Li content of primitive mantle is estimated at $1-1.8 \mathrm{ppm}$ (McDonough and Sun, 1995; Seitz and Woodland, 2000; Ottolini et al., 2004). 
Li has two isotopes ${ }^{6} \mathrm{Li}$ and ${ }^{7} \mathrm{Li}$ with a large relative mass difference $(\sim 15 \%)$ responsible for large (up to $60 \%$ o) isotopic fractionation of the ${ }^{7} \mathrm{Li} /{ }^{6} \mathrm{Li}$ ratios observed in terrestrial rocks (Chan, 2003). The $\delta^{7} \mathrm{Li}$ values $\left(\delta^{7} \mathrm{Li}=\left[\left({ }^{7} \mathrm{Li} /{ }^{6} \mathrm{Li}_{\text {sample }}\right) /\right.\right.$ $\left({ }^{7} \mathrm{Li} /{ }^{6} \mathrm{Li}_{\mathrm{LSVEC}}\right.$ standard $\left.\left.)-1\right] \times 1000\right)$ of terrestrial samples range from that of seawater (30-32\%o (Chan, 2003; Chan and Edmond, 1988)) to those of mantle-derived basalts (ca 1.59-6\%o (Chan et al., 1992; Moriguti and Nakamura, 1998; Tomascak et al., 1999a; Tomascak, 2004)). Recent studies have pointed out the potential of $\mathrm{Li}$ isotopes to constrain the fluid transfer processes occurring in subduction zones (Moriguti and Nakamura, 1998; Chan and Kastner, 2000; Chan and Leeman, 2002; Zack et al., 2003; Brooker et al., 2004; Elliott et al., 2004): isotopically heavy fluids are released from subducted slabs resulting in regions of the upper mantle with $\delta^{7} \mathrm{Li}>\mathrm{MORB}$, while the isotopically lighter dehydrated slab residue, subducted to great depth in the mantle, could be responsible for a distinct low $\delta^{7} \mathrm{Li}$ mantle. For example, low $\delta^{7} \mathrm{Li}$ values $(-11 \%$ o have been reported in eclogite (Zack et al., 2003) and in mantle xenoliths $\left(\delta^{7} \mathrm{Li}<-17 \%\right.$ (Nishio et al., 2004)). Such studies have assumed that there is no isotope fractionation at high temperature. Indeed, $\mathrm{Li}$ isotope fractionation is known to be very small when the temperature exceeds $350{ }^{\circ} \mathrm{C}$, and no isotopic changes occur during crystal-liquid fractionation at magmatic temperature (Chan et al., 1994; Tomascak et al., 1999b). However, Li isotope fractionation during high temperature rock-fluid (or melt) interactions needs further study. One possible high-temperature process that can fractionate $\mathrm{Li}$ isotopes is diffusion. $\mathrm{Li}$ is one of the most mobile alkali elements in silicate melts, and the higher diffusivity of ${ }^{6} \mathrm{Li}$ compared to ${ }^{7} \mathrm{Li}$ can create large isotopic fractionation (Richter et al., 2003). Such diffusion-related Li isotopic fractionation may contribute to the Li isotope heterogeneity observed in the mantle. For example, Lundstrom et al. (2005) recently reported $\mathrm{Li}$ isotopic fractionation by diffusion in the Trinity ophiolite of northern California.

Mantle peridotite xenoliths provide information about rock-fluid (or melt) processes at a microscopic scale. Expected Li heterogeneity is likely to be greater in xenoliths than in volcanic rocks, which only provide averaged information about their mantle source. At present, only a few isotopic determinations are available for mantle peridotites: whole rock data from a peridotite from Zabargad Island, Red Sea (Chan et al., 2002) and a few Li determinations on olivine and pyroxene (Jeffcoate et al., 2004; Nishio et al., 2004; Seitz et al., 2004; Bell et al., 2005), and amphibole (Kaliwoda et al., 2004) from mantle xenoliths.

We present here an ion microprobe (Secondary Ion Mass Spectrometry, SIMS) investigation of Li abundances and isotopic compositions of minerals from peridotite xenoliths from the French Massif Central. We compare xenoliths metasomatised by alkali silicate melts (Wagner et al., 1998) with unmetasomatised xenoliths from the same areas in order to describe the influence of a percolating fluid or melt on the Li distribution. To characterize the effect of varying degrees of metasomatism on $\mathrm{Li}$ distribution and isotopic composition in mantle peridotite, we have measured a relatively large number of samples. This large number precludes acquisition of detailed analytical profiles on individual grains in each sample, but several points were measured on each grain.

\section{SAMPLE LOCATION AND DESCRIPTION}

\subsection{Geological settings}

The French Massif Central lithospheric segment has been extensively rebuilt during the Cadomian (500 $600 \mathrm{Ma})$ and especially Variscan (280-350 Ma) orogenies (Matte, 1986, 1998). The Massif Central was an area of intense volcanism from the late Mesozoic up to the Quaternary (Maury and Varet, 1980). Several earlier geophysical studies (Perrier and Ruegg, 1973; Lucazeau et al., 1984) and more recent work (Granet et al., 1995; Zeyen et al., 1997; Granet et al., 2000) have shown that this activity is related to the upwelling of asthenospheric material, possibly related to a mantle plume located beneath the Eastern part of the Massif Central. Moreover, the geochemical and isotopic signatures of the volcanic rocks share similar characteristics with basalts associated with plume activity (Wilson and Downes, 1991a,b). However, the involvement of a mantle plume remains quite controversial, and a possible channeling of asthenospheric upwellings through lithospheric fractures is also invoked (Lenoir et al., 2000). Fluids and melts emanating from mantle upwellings of whatever origin, have greatly modified the lithosphere underlying the Massif Central (Downes and Dupuy, 1987; Wilson and Downes, 1991b; Vanucci et al., 1994; Zangana et al., 1997; Xu et al., 1998; Zangana et al., 1999; Lenoir et al., 2000).

In this study we focus on the Devès area, southeastern Massif Central in which the volcanic activity is younger than $5 \mathrm{Ma}$. It shows two interesting features: (i) it is located at the limit of a mantle with normal seismic characteristics towards the East and a low-velocity mantle towards the West, and it is spatially related to mantle upwelling as inferred from geophysical data (Nicolas et al., 1987; Mergoil and Boivin, 1993; Granet et al., 1995; Granet et al., 2000); and (ii) it is rich in mantle xenoliths scavenged during intense phreatomagmatic activity, and hydrated amphibolebearing xenoliths are particularly abundant. The xenoliths were collected in two diatreme volcanic breccia near Beyssac $\left(\mathrm{N} 45^{\circ} 3^{\prime}, \mathrm{E}^{\circ} 40^{\prime}\right.$, Marais de Limagne, samples labeled "L") and Saint Didier d'Allier (N44 58', E3 ${ }^{\circ} 41^{\prime}$, samples labeled "Sd").

\subsection{General petrographic features}

The nodules are fresh, and measure from 5 to $15 \mathrm{~cm}$ in diameter. They are rounded in shape or show planar faces. The xenoliths are typically encased in a thin basaltic rind (0.1-10 mm width) which is in sharp contact with the peridotite core. The xenoliths have not been affected by any invasion of basaltic melt or vapour along fractures and grain boundaries: we do not observed any patches of included basaltic melt, or glassy patches, or pervasive replacement of olivine by iddingsite for example. Even the smallest xenoliths are unaltered as shown by the uniform major element distribution in the minerals. The xenoliths are spinel 
lherzolites of Type I (Cr-diopside peridotite) of Frey and Prinz (1978), and some are amphibole-rich.

Samples without amphibole or with only traces of amphibole are referred to below as "anhydrous peridotites" and amphibole-bearing xenoliths as "hydrous peridotites". Sample Sdi can thus be considered as belonging to the "anhydrous peridotite" group, but is rather different in respect to its layered structure as described below. The major petrographic, mineralogical and chemical characteristics of the xenoliths are given in Table 1 and briefly summarized below.

The anhydrous peridotites belong to the protogranular textural type, while "intermediate" textures of the protogranular/porphyroclastic and porphyroclastic/equigranular types (using the terminology of Mercier and Nicolas, 1975) are observed in the hydrous xenoliths (Fig. 1). The protogranular xenoliths show no preferential orientation. They contain coarse- and medium-grained olivines (ol) and orthopyroxenes (opx) ranging from 3 to $6 \mathrm{~mm}$ in size with curvilinear crystal boundaries. Opx are generally free of exsolutions of clinopyroxene (cpx) and spinels (sp). Cpx and anhedral sp are generally smaller $(2 \mathrm{~mm})$, and $\mathrm{sp}$ are in contact with opx. The "intermediate textural types" contain two generations of crystals: large strained ol and opx porphyroclasts $(2-3 \mathrm{~mm}$ in size) and small $(100-700 \mu \mathrm{m})$ polygonal and annealed neoblasts of ol and cpx, which may exhibit typical $120^{\circ}$ triple junctions. Holly-leaf shaped sp commonly remain as relicts in amphibole (amp). The abundance and the size of the neoblasts are variable.

The xenolith texture would reflect a mostly undeformed subcontinental lithospheric mantle according to $\mathrm{Xu}$ et al. (1998). However, thorough recrystallization and annealing lead to coarse granular rocks with some characteristics not unlike those of the so-called protogranular type (e.g., paucity of deformation features and exsolutions), thus the relation between texture and deformation is difficult to ascertain. More important is the apparent correlation between the texture (the "deformation"?) and the presence of metasomatic phases: amp is preferentially concentrated in the "intermediate" textural type, as previously observed for porphyroclastic and equigranular hydrous peridotites from the Eifel (e.g., Stosch and Lugmair, 1986; Witt and Seck, 1989). Equilibrium temperatures calculated by the pyroxene thermometers (Wells, 1977; Brey and Köhler, 1990) range from 935 to $1091^{\circ} \mathrm{C}$ for both the anhydrous and hydrous samples, and no relationship has been found between texture and temperature. Modal abundances were determined on a single thin section of each sample by point counting several thousand points or by using the "Scion Image" image analysis software ${ }^{1}$ on an area covering the whole section. The major element whole-rock chemical compositions calculated from electron microprobe mineral analyses and their modal abundances are in good agreement with the measured whole-rock compositions. The main observed deviations could be corrected by minor adjustment of the estimated spinel abundance $(<1 \%)$. All samples are ol-rich (60-72 vol\%) lherzolites with variable

\footnotetext{
${ }^{1}$ The "Scion Image" image analysis software is available free of charge from http://www.scioncorp.com.
}

opx (7-26\% in volume) and cpx (2-18 vol\%). Note that the low cpx abundances in hydrous samples probably reflect their transformation, which is discussed below.

\section{ANALYTICAL METHODS}

Electron microprobe analyses were performed using a Cameca CAMEBAX SX 50 wavelength-dispersive system at the Centre d'Analyses CAMPARIS, University Pierre et Marie Curie (Paris 6), France. The operating conditions were: accelerating voltage $15 \mathrm{kV}$, beam current $40 \mathrm{nA}$ for oxides, olivines and pyroxenes, and $10 \mathrm{nA}$ for amphiboles and mica; counting times were never less than $20 \mathrm{~s}$, and a PAP matrix correction program (Pouchou and Pichoir, 1985) was employed. Standards were synthetic metal oxides and natural minerals.

$\mathrm{Li}$ contents and isotopic compositions were determined with the CRPG (Centre de Recherches Pétrographiques et Géochimiques, Centre National de la Recherche Scientifique, Nancy, France) Cameca IMS 3f ion microprobe, following the procedure of Decitre et al. (2001). The samples were gold-coated. A $10 \mathrm{kV}, 10-20 \mathrm{nA} \mathrm{O}^{-}$primary beam was focused on an area of $25 \mu \mathrm{m}$ in diameter. Positive secondary ions accelerated through $4.5 \mathrm{kV}$ were measured at low mass resolution $(M / \Delta M \sim 500)$ with an energy offset of $80 \pm 20 \mathrm{eV}$ for abundance determination, and at high mass resolution $(M / \Delta M \sim 1100)$ without energy offset $(0 \pm 50 \mathrm{eV})$ for isotopic composition determination. Secondary ions were counted with an electron multiplier in pulse counting mode. In order to obtain Li concentrations, the measured ${ }^{7} \mathrm{Li} /{ }^{30} \mathrm{Si}$ were corrected for the relative useful yields of Li and Si determined on standards (glasses Nazca, BCR-2G, BHVO-2G, NBS614, NBS616, cf. Decitre et al. (2001)) during the same analytical session. The analytical precision, including counting statistics and reproducibility ranges from 10 to $20 \%$ relative. For isotopic analyses, 100 cycles were measured with counting time of $12 \mathrm{~s}$ for ${ }^{6} \mathrm{Li}$ and $3 \mathrm{~s}$ for ${ }^{7} \mathrm{Li}$. The counting rate on ${ }^{7} \mathrm{Li}$ range from 3000 to $50,000 \mathrm{cps}$, depending on the sample $\mathrm{Li}$ content and the primary beam intensity. Note that both the background correction uncertainty $(\leqslant 0.1 \mathrm{cps})$ and the electron multiplier dead time correction uncertainty ( $\leqslant 2 \mathrm{~ns}$ ) are negligible in this range of counting rate. Li isotopic ratios are given in delta units using the $\delta^{7} \mathrm{Li}$ notation $\left(\delta^{7} \mathrm{Li}=\left(\left({ }^{7} \mathrm{Li} /{ }^{6} \mathrm{Li}_{\text {sample }}\right) /\right.\right.$ $\left.\left({ }^{7} \mathrm{Li} /{ }^{6} \mathrm{Li}_{\text {LSVEC }}\right)-1\right) \times 1000$, with ${ }^{7} \mathrm{Li} /{ }^{6} \mathrm{Li}_{\mathrm{LSVEC}}=12.0192$, (Flesh et al., 1973)). Cpx BZ226 and BZ CG, and Nazca glass (Decitre et al., 2001) were used as standards. Decitre et al. (2001) and Beck et al. (2004) showed that there is an absence of matrix effects on the $\mathrm{Li}$ instrumental isotopic fractionation using the same instrumental set up at the IMS $3 \mathrm{f}$ in Nancy. Note that the measured minerals in our samples display no chemical variation at the mineral scale and a very limited range of chemical composition for the whole set, with high $\mathrm{Mg}$ numbers (86-90) similar to the standard ones. The analytical precision, including counting statistic and standard reproducibility ranges from 1.5 to $2.5 \% \circ(2 \sigma)$ depending on the mineral Li contents. The precise location of the analytical SIMS points is given on sample maps in electronic annexes W4439-EA-1 and W4339EA-2. 
Table

Summary of petrographic features

\begin{tabular}{|c|c|c|c|c|c|c|c|c|}
\hline \multicolumn{2}{|c|}{ Texture and description } & Grain size $(\mathrm{mm})$ & ol $(\%)$ & opx $(\%)$ & $\operatorname{cpx}(\%)$ & $\operatorname{sp}(\%)$ & $\operatorname{amp}(\%)$ & Temperatu \\
\hline \multicolumn{9}{|c|}{ Anhydrous peridotites } \\
\hline L17 & $\begin{array}{l}\text { Protogranular } \\
\text { ol: a few kink bands } \\
\text { pyr: no exsolutions } \\
\text { sp: in contact with pyr }\end{array}$ & $\begin{array}{l}\text { Coarse-grained } \\
\text { ol, opx: 4-6 } \\
\text { cpx: } 2-3 \\
\text { sp: } 1.5-2\end{array}$ & 67 & 19 & 10 & 4 & & $1019-1071$ \\
\hline L2 & $\begin{array}{l}\text { Protogranular } \\
\text { ol: a few kink bands, } \\
\text { opx: no exsolutions } \\
\text { cpx: frequent exsolutions } \\
\text { sp: in contact with pyr }\end{array}$ & $\begin{array}{l}\text { Coarse/medium } \\
\text { grained } \\
\text { ol, opx: } 2-3 \\
\text { cpx: } 1.5 \\
\text { sp: } 1.5-2\end{array}$ & 60 & 17 & 18 & 5 & traces & $935-964$ \\
\hline L22 & $\begin{array}{l}\text { Protogranular } \\
\text { ol: kink banded } \\
\text { opx, cpx: no exsolutions } \\
\text { sp: in contact with pyr }\end{array}$ & $\begin{array}{l}\text { Coarse-grained } \\
\text { ol, opx: } 4-5 \\
\text { cpx: } 1.5-2 \\
\text { sp: } 1.5\end{array}$ & 62 & 22 & 11 & 5 & & $1033-1082$ \\
\hline \multicolumn{9}{|c|}{ Anhydrous layered peridotite } \\
\hline Sdi & $\begin{array}{l}\text { Protogranular, tendency to porphyroclastic } \\
\text { layered sample: ol-rich bands (1) and } \\
\text { sp + pyr-rich bands ( } 2 \text { ) } \\
\text { ol: kink banded, pyr: no exsolutions } \\
\text { sp: elongated, in contact with pyr }\end{array}$ & $\begin{array}{l}\text { Medium-grained } \\
\text { (1) ol, opx : } 2-3 \\
\text { (2) opx, cpx: } 0.5-1.5 \\
\text { sp: } 1 \times 0.2-0.4\end{array}$ & 72 & 14 & 9 & 5 & traces & $975-989$ \\
\hline \multicolumn{9}{|c|}{ Hydrous peridotites } \\
\hline $\mathrm{Sd} 27$ & $\begin{array}{l}\text { Protogranular } \\
\text { sp-rich bands } \\
\text { ol: frequent kink bands } \\
\text { pyr: rare exsolutions } \\
\text { sp: elongated, only in bands } \\
\text { amp (1) rare disseminated grains: } \\
\text { (2) coarse grains or clusters around sp: }\end{array}$ & $\begin{array}{l}\text { Coarse-grained } \\
\text { ol, opx: up to } 3-4 \\
\text { cpx: } 1-2 \\
\text { sp: } 1-2 \\
\text { amp (1): } 0.2 \\
\text { amp (2): } 0.5-1\end{array}$ & 69 & 26 & 2 & 1 & $2^{*}$ & $935-957$ \\
\hline L50 & $\begin{array}{l}\text { Porphyroclastic/equigranular } \\
\text { few porphyroclasts of kink banded ol } \\
\text { and opx with exsolutions: } \\
\text { ol and opx neoblasts of two different } \\
\text { sizes and rare cpx: } \\
\text { sp: relics in amp } \\
\text { amp: (1) in bands, (2) disseminated } \\
\text { neoblasts of variable size }\end{array}$ & $\begin{array}{l}\text { Fine-grained } \\
\text { ol, opx: } 2 \\
\text { ol,opx: } 0.4 ; 0.7-0.8 \\
\text { cpx }<0.3 \\
\text { sp: } 0.3-0.4 \\
\text { amp (1): } 1-2 \\
\text { amp (2): } 0.3-0.6\end{array}$ & 69 & 7 & 2 & 2 & 20 & $1032-1091$ \\
\hline
\end{tabular}



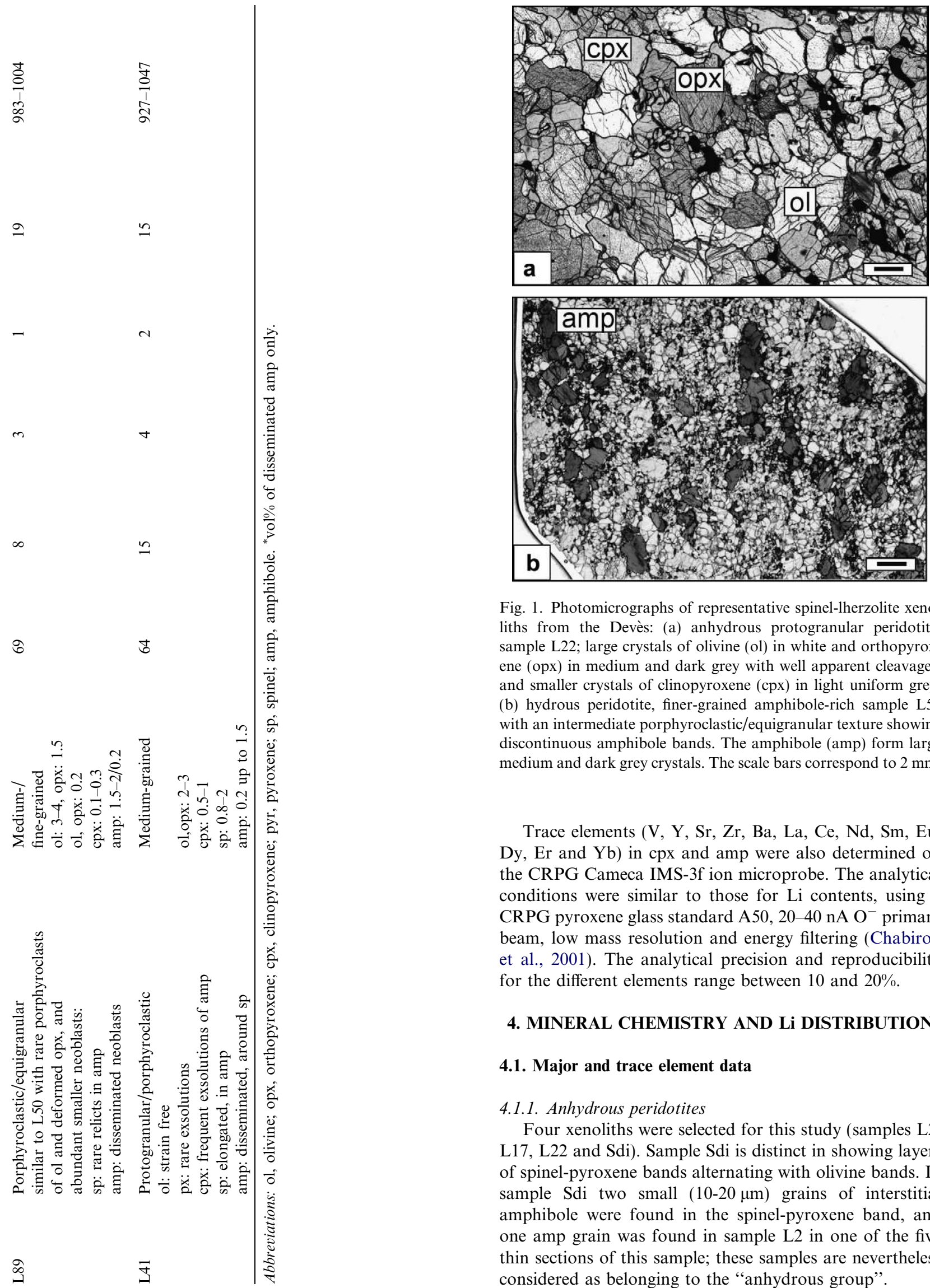

Fig. 1. Photomicrographs of representative spinel-lherzolite xenoliths from the Devès: (a) anhydrous protogranular peridotite, sample L22; large crystals of olivine (ol) in white and orthopyroxene (opx) in medium and dark grey with well apparent cleavages, and smaller crystals of clinopyroxene (cpx) in light uniform grey. (b) hydrous peridotite, finer-grained amphibole-rich sample L50 with an intermediate porphyroclastic/equigranular texture showing discontinuous amphibole bands. The amphibole (amp) form large medium and dark grey crystals. The scale bars correspond to $2 \mathrm{~mm}$.

Trace elements (V, Y, Sr, Zr, Ba, La, Ce, Nd, Sm, Eu, Dy, Er and $\mathrm{Yb}$ ) in cpx and amp were also determined on the CRPG Cameca IMS-3f ion microprobe. The analytical conditions were similar to those for $\mathrm{Li}$ contents, using a CRPG pyroxene glass standard A50, 20-40 nA O ${ }^{-}$primary beam, low mass resolution and energy filtering (Chabiron et al., 2001). The analytical precision and reproducibility for the different elements range between 10 and $20 \%$.

\section{MINERAL CHEMISTRY AND Li DISTRIBUTION}

\subsection{Major and trace element data}

\subsubsection{Anhydrous peridotites}

Four xenoliths were selected for this study (samples L2, L17, L22 and Sdi). Sample Sdi is distinct in showing layers of spinel-pyroxene bands alternating with olivine bands. In sample Sdi two small $(10-20 \mu \mathrm{m})$ grains of interstitial amphibole were found in the spinel-pyroxene band, and one amp grain was found in sample L2 in one of the five thin sections of this sample; these samples are nevertheless considered as belonging to the "anhydrous group". 
The anhydrous lherzolites are coarse-grained rocks of the protogranular type (Table 1). They have a relatively fertile composition (9-11 vol\% cpx) with high cpx/opx ratios $(0.5-0.6)$, and contain $4-5$ vol\% spinel. Sample L2 is particularly cpx-rich (18 vol\%). Minerals of all samples are nearly homogeneous within analytical uncertainty, with no significant intra- or inter-grain variations. $\mathrm{Ol}$, opx and cpx are in chemical equilibrium with high $\mathrm{Mg} \#(\mathrm{Mg} \#=100 * \mathrm{Mg} /$ $(\mathrm{Mg}+\mathrm{Fe})$ ) of $\sim 90$ (Table 2). Spinel are Al-rich (52-58 $\mathrm{wt} \% \mathrm{Al}_{2} \mathrm{O}_{3}$ ). The phases display a rather constant composition: $\mathrm{Cr} \#(\mathrm{Cr} \#=100 * \mathrm{Cr} /(\mathrm{Cr}+\mathrm{Al}))$ of cpx mostly about 7 ( $\sim 9$ in Sdi), high $\mathrm{Al}_{2} \mathrm{O}_{3}$ contents in opx (4-5 wt\%) and low $\mathrm{Cr} \#(11-16)$ in sp. These features suggest low degrees of partial melting. The cpx rare earth element (REE) chondrite-normalised patterns of the samples L17 and L2 are LREE-depleted (Fig. 2 and Table 3), therefore, excluding their re-enrichment by a late metasomatism. Note that both cpx and amp are LREE-depleted in sample L2. On the contrary, the samples L22 and Sdi are LREE-enriched (La/ $\mathrm{Yb})_{N}=\sim 5.5$ ) (Fig. 2 and Table 3). The absence of amp in sample L22 suggests cryptic rather than modal metasomatism.

\subsubsection{Hydrous peridotites}

Three spinel lherzolites (L41, L50 and L89) and one composite xenolith $(\mathrm{Sd} 27)$ were selected. In the peridotite, amp occurs as disseminated phases, which generally develop at the expense of spinel $+\mathrm{cpx}$, and may also fill veinlets and form continuous or discontinuous bands with variably abundant relict spinels (Fig. 1b). The different types of amphibole occurrences are not mutually exclusive. The composite sample $\mathrm{Sd} 27$ is surrounded by a phlogopite-bearing hornblendite selvage ( $5 \mathrm{~mm}$ thick), which represents the remnant of a dike margin, and contains several $1 \mathrm{~mm}$ thick amphibole veins. The contacts between the peridotite and the selvage or the veins are sharp.

The hydrous samples are mostly porphyroclastic or intermediate between porphyroclastic and equigranular textural types and are more fine-grained than the anhydrous samples. They are characterised by low abundances of relic cpx (2-4 vol\%) and sp (<1-2 vol\%) and high amp (15-20 vol\%) (Table 1), which in some cases seems to pervasively invade the peridotite. In the veined composite sample $\mathrm{Sd} 27$, disseminated amp is scarce and represents only 2 $\mathrm{vol} \%$ of the rock. In these hydrous peridotites the formation of amp after cpx has concealed the original fertility or depletion characteristics, which are no longer reflected in cpx abundances or cpx/opx ratios. Nevertheless, the amounts of relic cpx plus newly formed amp after cpx are likely to support a rather fertile composition for the hydrous samples, similarly to the anhydrous lherzolites. As observed in the anhydrous peridotites, ol and pyroxenes are in equilibrium with similar $(\sim 90)$ or slightly lower $\mathrm{Mg \#} \mathrm{(88-89)} \mathrm{in} \mathrm{samples} \mathrm{L50} \mathrm{and} \mathrm{Sd27.} \mathrm{The} \mathrm{pyroxenes} \mathrm{have}$ lower $\mathrm{Al}_{2} \mathrm{O}_{3}$ contents: $4-5 \mathrm{wt} \%$ compared to $7 \mathrm{wt} \%$ for $\mathrm{cpx}$ in the anhydrous samples; $2-3 \mathrm{wt} \%$ compared to $4-6 \mathrm{wt} \%$ for opx. Cpx have higher variable $\mathrm{Cr} \#(9-15)$. Sp contain less $\mathrm{Al}\left(28-38 \mathrm{wt}^{\%} \% \mathrm{Al}_{2} \mathrm{O}_{3}\right)$ and are $\mathrm{Cr}$-rich compared to those of the anhydrous samples, except sample L41 in which sp resemble those of anhydrous samples. Sample
$\mathrm{Sd} 27$ shows a particularly variable $\mathrm{Cr}$ content $(\mathrm{Cr} \#=24.5-49.6)$. Thus, the variations likely result from a metasomatic overprint which is also suggested by the lack of a clear negative trend in the diagram $\mathrm{TiO}_{2}$ versus $\mathrm{Al}_{2} \mathrm{O}_{3}$ in cpx from the anhydrous and hydrous samples (not shown). Disseminated amp are Cr-rich $\left(\mathrm{Cr}_{2} \mathrm{O}_{3}=0.9-1.3\right.$ $w t \%)$ pargasites $\left(\mathrm{TiO}_{2}<0.7 \mathrm{wt} \%\right)$, whereas vein and selvage amp are kaersutites $\left(\mathrm{TiO}_{2}=\right.$ up to $4.4 \mathrm{wt} \%$ with low $\mathrm{Cr}_{2} \mathrm{O}_{3}$ $\left(<0.2 \mathrm{wt}^{\%} \%\right.$ ) (Table 2). The amp have lower Mg\# (86-88) than the other silicates (88-90) (Table 2). The REE profiles are characterized by a strong enrichment of LREE over HREE (Fig. 2 and Table 3) both in amp and cpx ((La/ $\mathrm{Yb})_{N}=18-34$, and lower values $(\sim 9)$ for sample L41). Amp from the hornblendite selvage of sample $\mathrm{Sd} 27$ has overall higher REE abundances and are less LREE-enriched (average $(\mathrm{La} / \mathrm{Yb})_{N}$ values of $\sim 8.5$ ).

\subsubsection{Amphibole and clinopyroxene compositional variations}

As shown by the composite sample $\mathrm{Sd} 27$, amp composition varies progressively as a function of increasing distance from the selvage, for example the Ti content decreases while the $\mathrm{Cr}$ content increases in relation with the progressive destabilisation of spinel (Fig. 3). Moreover, a progressive REE enrichment is observed in both amp and cpx (Fig. 2) at the proximity of the amp selvage/peridotite contact, while the composition of the amp far from the selvage matches that of the disseminated grains, and cpx analyzed away from the selvage have the REE patterns of cpx from anhydrous peridotites. In a previous study, compositional gradients in amp (decrease in $\mathrm{Ti}, \mathrm{Fe}, \mathrm{K}$; increase in $\mathrm{Cr}$ and $\mathrm{Na}$ ) have already been observed along the veins, i.e. along melt percolation paths, and away from the peridotite/hornblendite contact (Fig. 1 in Wagner et al., 1998), demonstrating that the peridotite has been modified adjacent to hydrous selvages by reactions with a metasomatic melt emanating from the dike.

\subsection{Li distribution}

\subsubsection{Li abundances}

Bulk Li compositions estimated by combining the measured $\mathrm{Li}$ concentrations with modal mineral abundances give $0.8-1.1 \mathrm{ppm}$ in the anhydrous samples, values in accordance with estimations reported for fertile to slightly depleted lithospheric mantle (Seitz and Woodland, 2000) and references therein, whereas hydrous samples have higher (1.4 $4 \mathrm{ppm})$ bulk Li contents. The average and the range of Li contents in the different phases of each sample are given in Table 2, in order to visualize the degree of $\mathrm{Li}$ heterogeneity.

In three of the anhydrous samples, ol show little variation in average Li contents, between 1.1 and 1.4 ppm (Table 2). Opx and cpx contain, respectively, $0.2-0.7 \mathrm{ppm}$ and 0.4 $0.9 \mathrm{ppm}$. The mineral phases from the layered sample Sdi have higher Li abundances, $3.2 \mathrm{ppm}$ in ol, $1.5 \mathrm{ppm}$ in opx and $1.3 \mathrm{ppm}$ in cpx. The hydrous samples clearly show enrichment of $\mathrm{Li}$ in ol (1.5-5.0 ppm), opx (1.1-2.4 ppm) and cpx (2.4-5.4 ppm). The disseminated and vein amphiboles (amp) incorporate less $\mathrm{Li}$ than the co-existing phases: Average Li content of amp ranges from 1.1 to $1.4 \mathrm{ppm}$ 
Table 2

Representative mineral analyses

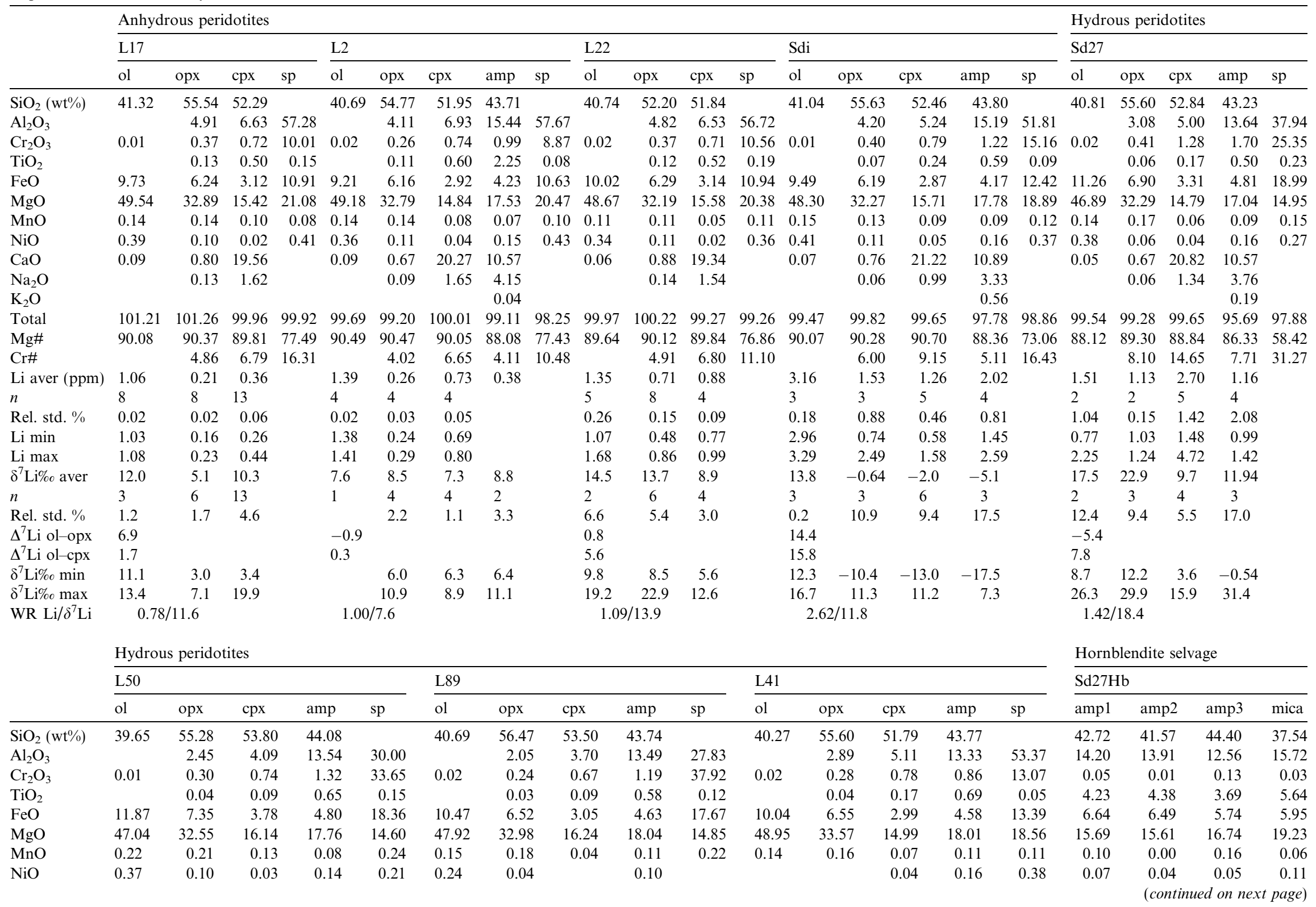


Table 2 (continued)

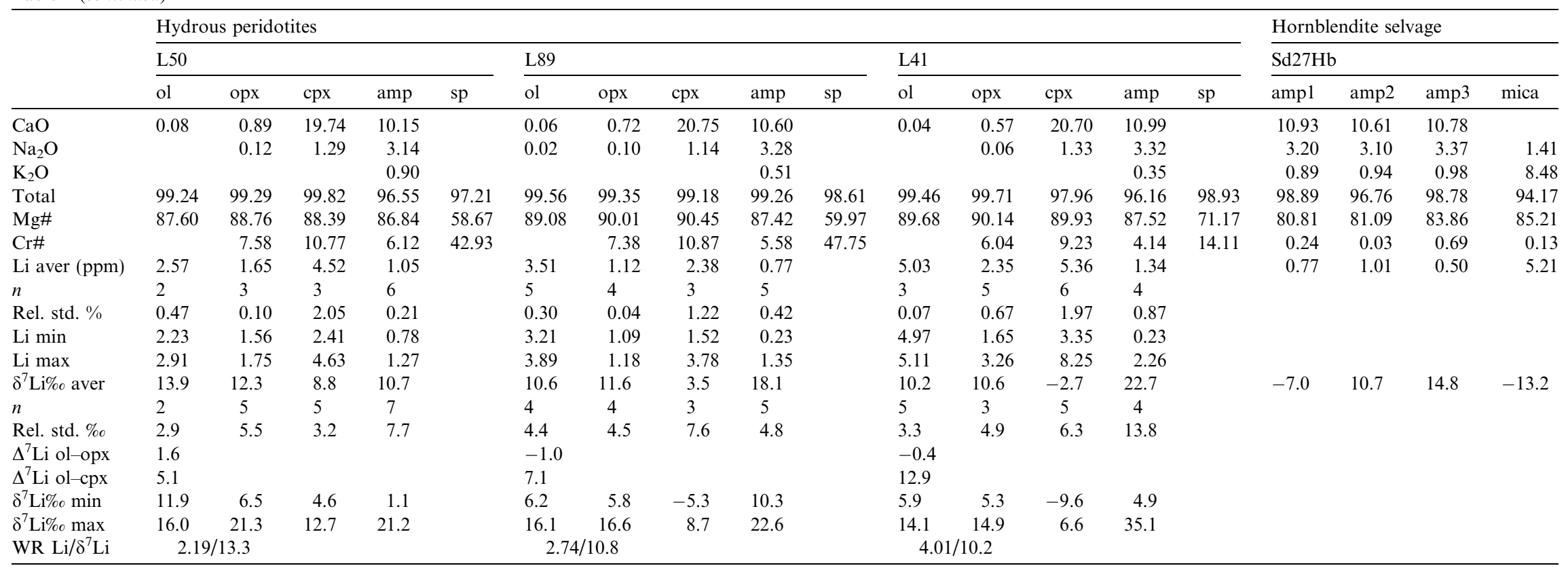

Major element analyses are average values. Mineral abbreviations as in Table $1 . \mathrm{Mg} \#$ and $\mathrm{Cr} \#$ as in Table $1 . \mathrm{Li}$ aver and $\delta^{7} \mathrm{Li} \%$ aver are the average values on $\mathrm{n}$ analyses. Rel. std $=$ relative standard deviation on the measured value to be comparable with the analytical error (10-20\% on Li contents and $1.5-2.5 \%$ on $\left.\delta^{7} \mathrm{Li}\right)$. min and max refer, respectively, to the lowest and the highest measured values in different grains. WR $\mathrm{Li}$ = whole-rock Li contents. In the hornblendite selvage $\mathrm{Sd} 27 \mathrm{Hb}$, the amp analysed are located from close to the host basalt (amp \#1) up to the contact with the peridotite $(\mathrm{amp} \# 3$ ). 

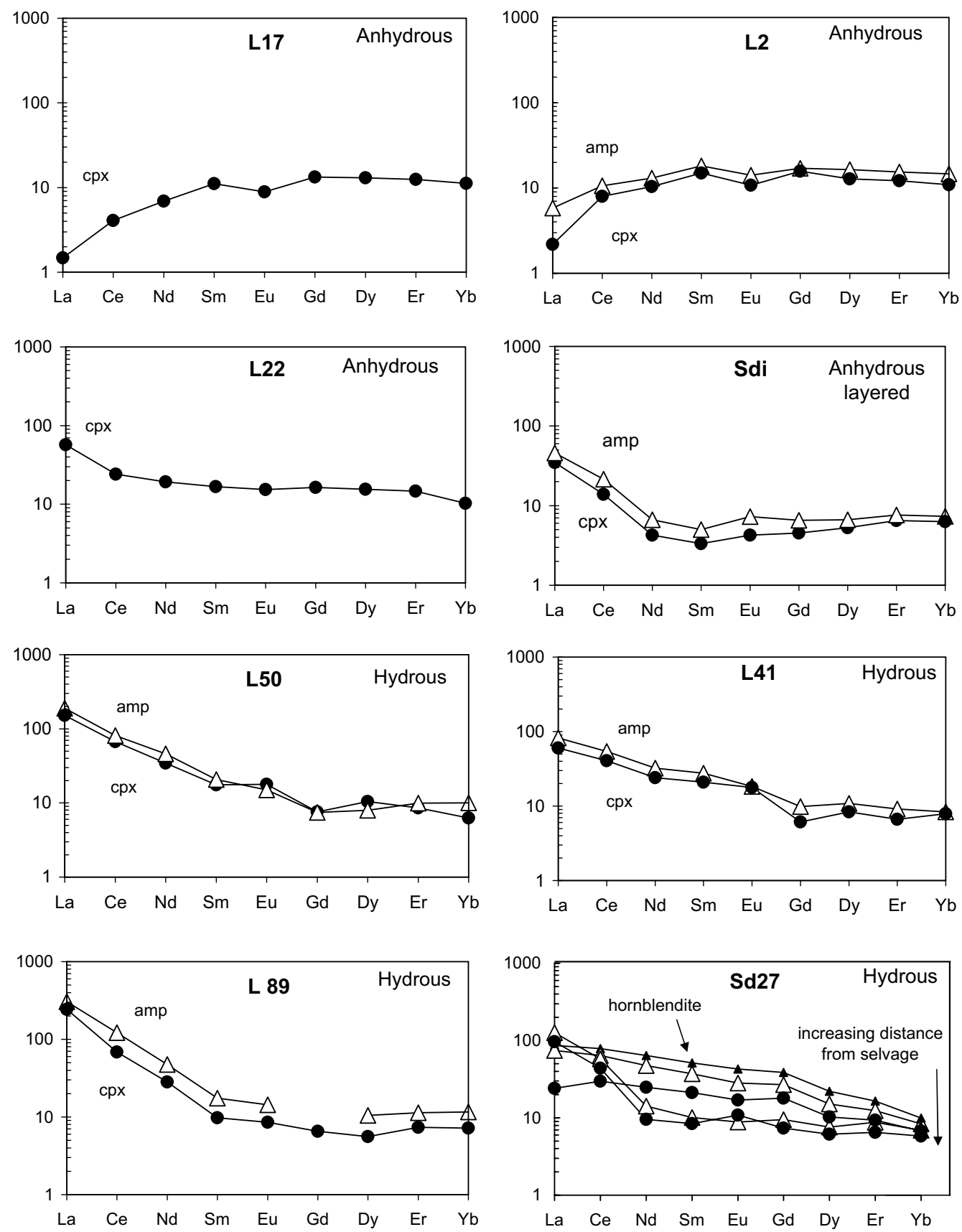

Fig. 2. Chondrite-normalized REE plots for $\mathrm{cpx}$ (solid circles) and amp (open triangles) from the selected rocks. For the hydrous sample $\mathrm{Sd} 27$ the small solid triangles correspond to amp from the hornblendite selvage. Analyses are given in Table 3. Chondrite values from McDonough and Sun (1995). Abbreviations as in Fig. 1.

except in one sample (L89) where it is lower (0.8 ppm). Amp from the hornblendite selvage of sample $\mathrm{Sd} 27 \mathrm{Hb}$ shows similar Li contents varying between 0.5 and $1.0 \mathrm{ppm}$, whereas the mica contains higher Li (5.2 ppm) (Table 2).

The range of the measured $\mathrm{Li}$ values in the different anhydrous phases is wider in the hydrous samples $(0.8-$ $5.1 \mathrm{ppm})$ compared to that of the anhydrous samples (0.2-1.7 ppm, excluding sample Sdi up to $3.3 \mathrm{ppm}$ ) (Table 2 and Fig. 4). In amphibole, the variations in average values observed either in a single crystal or in several crystals from one sample are small $(0.2-2.3 \mathrm{ppm})$ and lower than in the cpx (1.5-8.3 ppm) (Table 2).

\subsection{2. $\delta^{7}$ Li values}

Average $\delta^{7} \mathrm{Li}$ values range from +7 to $+15 \%$ in ol, from -0.6 to $+14 \%$ in opx and from -2 to $+10 \%$ in cpx from the anhydrous lherzolites (Table 2). In the amphibole-bearing rocks average $\delta^{7} \mathrm{Li}$ values both overlap and extend beyond this range of values up to higher values in ol $(+17.5 \%$ ) and opx $(+22.9 \%)$, and vary widely in cpx 


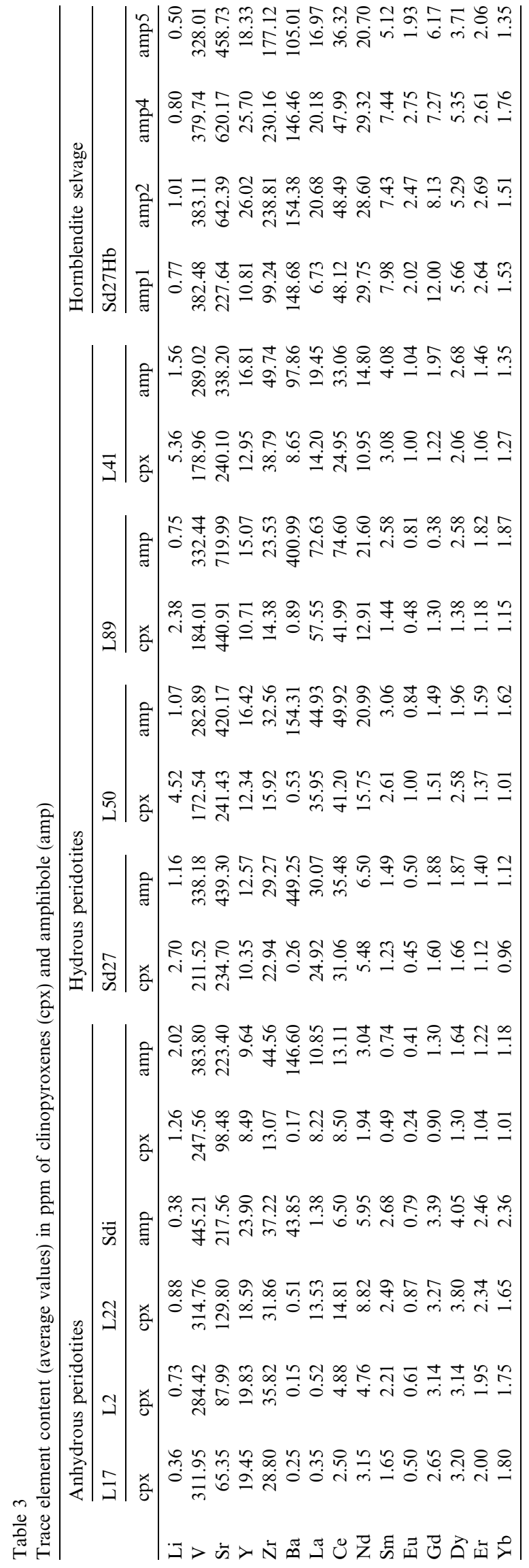

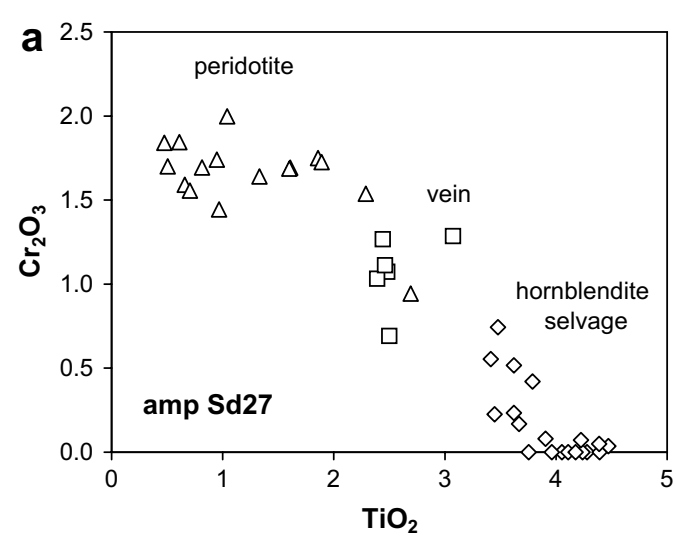

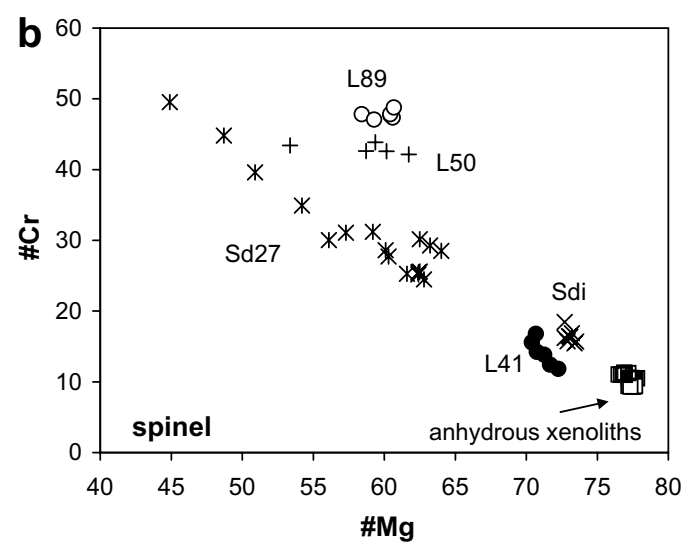

Fig. 3. (a) Variation of $\mathrm{Cr}_{2} \mathrm{O}_{3}$ versus $\mathrm{TiO}_{2}$ contents in amp from sample $\mathrm{Sd} 27$ : triangles, amp from the peridotite; squares, vein amp; diamonds, amp from the hornblendite selvage: the Ti-richest amp are close to the contact with the basaltic host. Oxides in wt $\%$. (b) $\mathrm{Cr} \#(\mathrm{Cr} \#=100 *(\mathrm{Cr} /(\mathrm{Cr}+\mathrm{Al}))$ versus $\mathrm{Mg} \#(\mathrm{Mg} \#=100 *(\mathrm{Mg} /$ $(\mathrm{Mg}+\mathrm{Fe}))$ in $\mathrm{sp}$ from the different xenoliths. Spinels from the anhydrous samples show a restricted range both in $\mathrm{Cr} \#$ and $\mathrm{Mg \#}$, while in hydrous samples sp are Cr-enriched and show large variations in sample $\mathrm{Sd} 27$. Sp from the hydrous peridotite $\mathrm{L} 41$ have not been modified by amp crystallization. Abbreviations as in Fig. 1.

$\left(-3\right.$ to $+10 \%$ ). Low negative $\delta^{7} \mathrm{Li}$ values are observed in some cpx from the hydrous samples $(-9.7 \%$ ) and in opx $(-10.4 \% o)$ and cpx $(-13 \%)$ from the layered sample Sdi. Ol generally has the highest $\delta^{7} \mathrm{Li}$ values except in sample $\mathrm{Sd} 27$, followed by opx and then by cpx. Compared to the few data available in the literature, $\delta^{7} \mathrm{Li}$ values are higher in our anhydrous samples than those reported in mildly depleted lherzolites from Eifel, Vitim and San Carlos (Seitz et al., 2004). Furthermore, in our samples the pyroxenes have a wider range of $\delta^{7} \mathrm{Li}$ values with negative values. Extremely low $\delta^{7} \mathrm{Li}$ values $(-4$ down to $-17 \%$ o) are known in cpx from anhydrous spinel lherzolite xenoliths from Kurose, Japan, and Sikhote-Alin, Russia (Nishio et al., 2004). The average amp $\delta{ }^{7} \mathrm{Li}$ mostly range from +10 to $+23 \%$, although in sample Sdi the average $\delta^{7} \mathrm{Li}$ is negative (Table 2). Amp $\delta^{7} \mathrm{Li}$ values are similar to or higher than the $\delta^{7} \mathrm{Li}$ values of the other silicate phases. In contrast, the only other value of $\mathrm{Li}$ isotopic composition in amp reported in the literature (Eifel, (Seitz et al., 2004)) to our knowledge is lower than in the coexisting phases. 
Li (ppm)
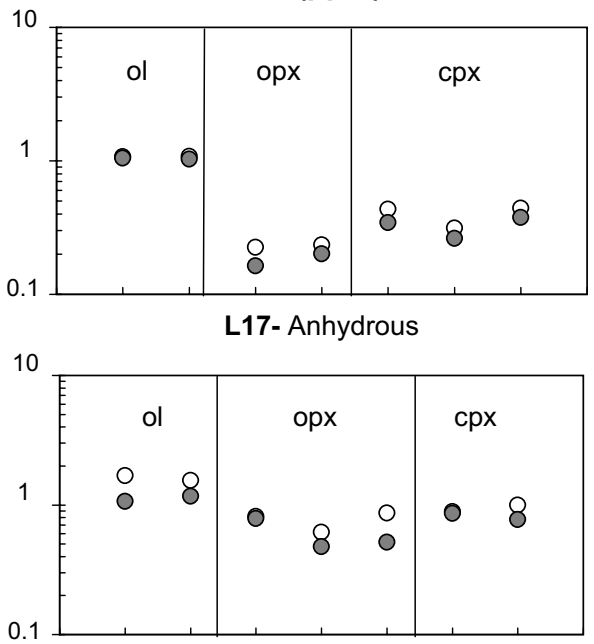

L22- Anhydrous
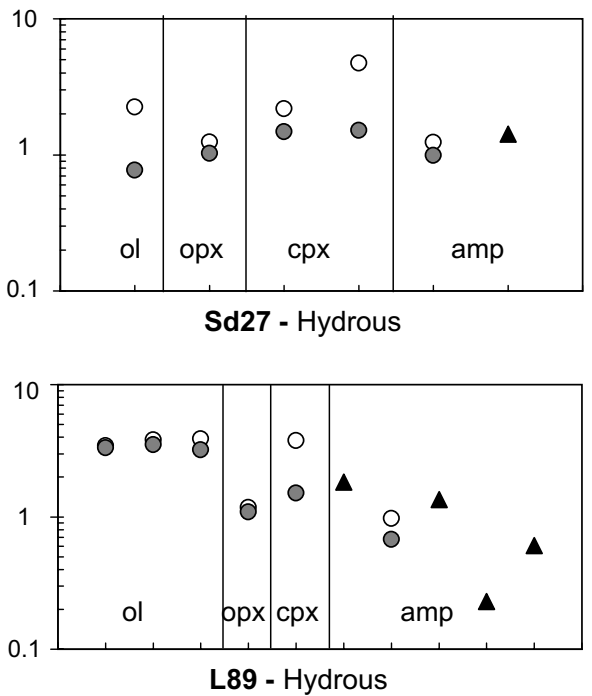

Li (ppm)
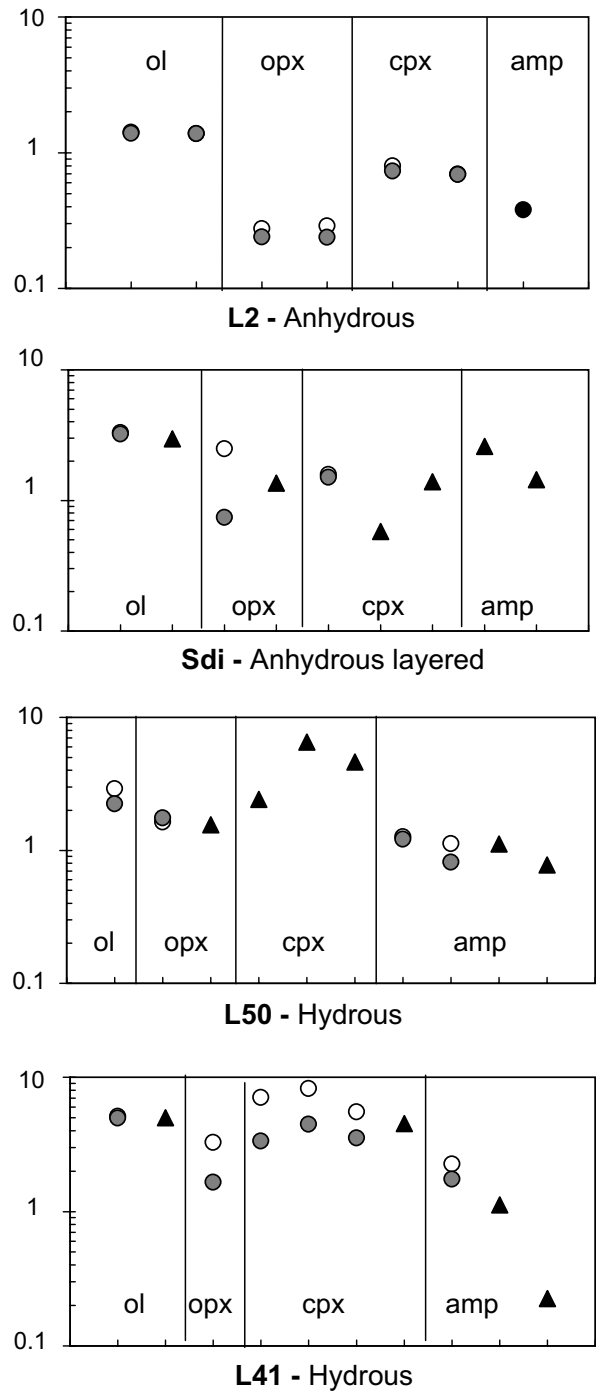

Fig. 4. Li variations (ppm) in the different phases analysed in each samples: e.g., 2 ol, 2 opx and 3 cpx in sample L17. Maximum and minimum values are plotted as open and grey circles, respectively. Solid triangles correspond to phases with only one analytical point available.

The different anhydrous phases from anhydrous and hydrous samples show inter- and intra-grain variations in $\mathrm{Li}$ isotopic ratios (Table 2). With the exception of pyroxene grains from sample Sdi, intra-grain variations are smaller (less than $10 \%$ and mostly less than 6\%o) in all phases from the anhydrous samples than in the hydrous samples (up to $18 \%$ ) (Fig. 5). In the layered sample Sdi, the opx, and cpx of the amp-rich layers show a large range of $\mathrm{Li}$ isotopic ratios (12 and 20\%o, respectively), similar to those of the hydrous peridotite. A core to rim variation in $\delta^{7} \mathrm{Li}$ of $8 \%$ has been reported in ol and opx from lherzolite xenoliths (Jeffcoate et al., 2004), and intra-granular variations up to 15\% in olivine from San Carlos (Bell et al., 2005).

Similar to the anhydrous silicates, amp show a wide range of intra-grain $\delta^{7} \mathrm{Li}$ values $(2-27 \%$ ) (Fig. 5). In amp from the hornblendite selvage of sample $\mathrm{Sd} 27 \mathrm{Hb}$, the $\mathrm{Li}$ isotopic ratios vary from -7 to $+15 \%$, and the coexisting mica is lighter $(-13.2 \%$ ) (Table 2$)$.

\section{Li BEHAVIOUR DURING MANTLE METASOMATISM}

\subsection{Li abundances and partial melting in anhydrous samples}

In olivine from most of the anhydrous samples, Li abundances plot on the trend defined by anhydrous spinel and garnet lherzolites, and inclusions of peridotitic composition (Seitz and Woodland, 2000; Seitz et al., 2003; Ottolini et al., 2004) (Fig. 6). Therefore, the Li contents of olivine in these samples reflect the degree of melt depletion experienced by the peridotites. Two of the hydrous samples and the layered sample Sdi have olivine $\mathrm{Mg \#}$ similar to those from the anhydrous samples suggesting a similar degree of melt depletion, while the two other hydrous peridotites are less depleted. Most of the hydrous samples and sample Sdi do not plot on the trend defined above, indicating a metasomatic overprint as in the Pyrenean metasomatised 
$\delta^{7} \operatorname{Li}(\%)$
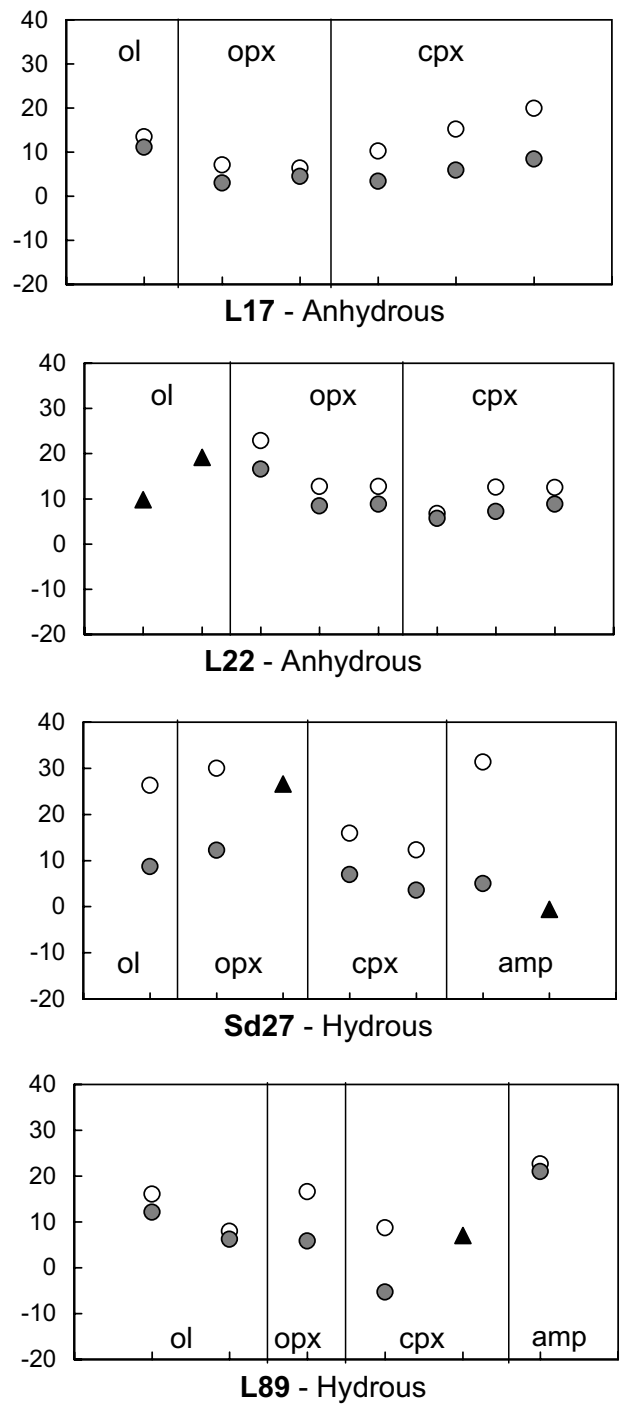

$\delta^{7} \operatorname{Li}(\%)$
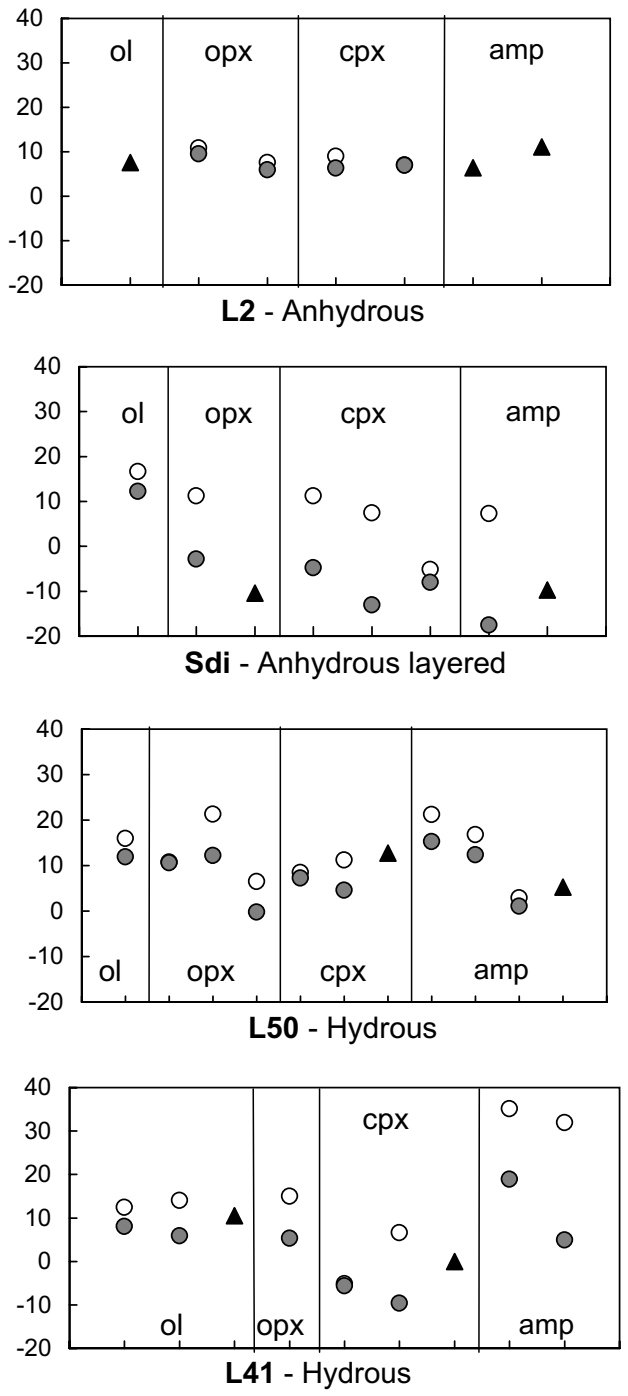

Fig. 5. Same as Fig. 4 for variations in $\delta^{7} \mathrm{Li}(\%)$. Maximum and minimum values are plotted as open and grey circles, respectively. Solid triangles correspond to phases with only one analytical point available.

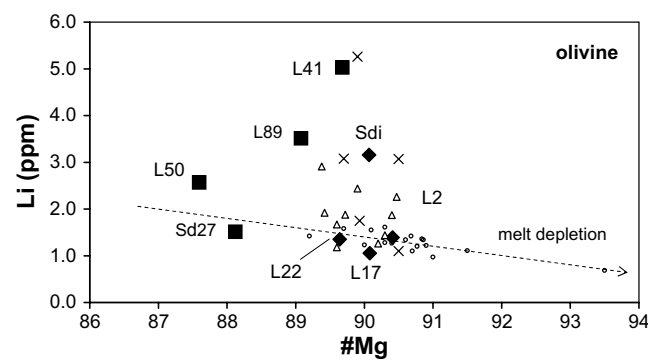

Fig. 6. Li ( $\mathrm{ppm})$ versus $\mathrm{Mg \#}$ in ol from the anhydrous (solid diamonds) and hydrous xenoliths (solid squares) and data from the literature (Seitz and Woodland, 2000; Seitz et al., 2003; Ottolini et al., 2004): open circles, spinel- and garnet-bearing equilibrated lherzolite xenoliths and peridotitic inclusions in diamond; open triangles, lherzolites from the French Massif Central; crosses, nonequilibrated metasomatised peridotites from the French Pyrénées. The dashed line corresponds to the trend defined by equilibrated peridotites from the literature. lherzolites (Seitz and Woodland, 2000) (Fig. 6). Metasomatic Li enrichment of ol from sample Sdi may have been facilitated by the higher permeability generated by the layered structure. This metasomatic signature also affects the bulk $\mathrm{Li}$ content which increases (from 0.8 to $1.1 \mathrm{ppm}$ ) in the anhydrous samples up to $4 \mathrm{ppm}$ in the hydrous samples (Table 2).

\subsection{Li partition relationships between ol, opx and cpx}

In the anhydrous samples, $\mathrm{Li}$ is preferentially incorporated into olivine compared to pyroxenes $[\mathrm{Li}(\mathrm{ol})>$ $\operatorname{Li}(\operatorname{cpx})>\operatorname{Li}($ opx $)]$. As indicated by the hydrous lherzolites, the metasomatic process appears to have preferentially enriched cpx in Li such that the Li content of cpx is in all cases higher than opx and in most cases the same as or higher than ol. (Table 2). In the anhydrous samples, the apparent Li partition coefficients vary between $1.5-2.9$ for ol/cpx, $1.9-5.1$ for 
ol/opx and 0.4-1.2 for opx/cpx, and are lower in the hydrous lherzolites $(0.6-1.4,1.3-3.1$ and $0.4-0.5$, respectively) (Table 4). These values are similar to values previously reported in the literature (Seitz and Woodland, 2000; Kaliwoda and Altherr, 2003; Seitz et al., 2003; Ottolini et al., 2004; Woodland et al., 2004) (Fig. 7). Note that the ol/opx partition coefficient for L2 and L17 are higher by a factor 2 than for the other samples and in the literature, due to a lower Li content (down to $0.2 \mathrm{ppm}$ ) of the opx. Furthermore, these two samples have the lowest Li contents both in opx and cpx. The REE are also depleted, suggesting that all the trace elements distribution may have been modified by melt extraction without further enrichment.

Our samples are spinel lherzolites that have been equilibrated in a restricted range of temperature $\left(950-1050^{\circ} \mathrm{C}\right)$ and of pressure. Thus, the Li composition should vary with the major element compositions of the phases. The interphase partitioning remains constant when equilibrium is maintained between phases and, thus, deviations from the equilibrium partitioning values reflect overprinting metasomatic processes. The anhydrous samples fall within the trend of equilibrium partitioning between ol/cpx and opx/ cpx defined by equilibrated lherzolites from the literature (Seitz and Woodland, 2000; Kaliwoda and Altherr, 2003; Ottolini et al., 2004) (Fig. 7), ranging from the more depleted L17 sample to sample Sdi with Li contents close to the upper limit of the reported Li values for equilibrated lherzolites. In the hydrous samples the Li content increases in all phases (cf. Section 4.2.1). The distribution of Li remains unchanged between ol and opx but not with cpx (Fig. 7). The hydrous samples typically deviate from the equilibrium partition trend showing a preferential enrichment of Li in cpx (Fig. 7b and c), as previously noticed for peridotites metasomatised by infiltrating alkali basalt melts (Seitz and Woodland, 2000) (Fig. 7). In the hydrous sample L89, the analyzed ol and cpx are neoblasts which plot within the equilibrium trend indicating that re-equilibration has been achieved through diffusion in this sample.

\subsection{Li and other fluid mobile elements}

In the anhydrous samples, which reflect similar degrees of partial melting, the REE patterns are variable, either
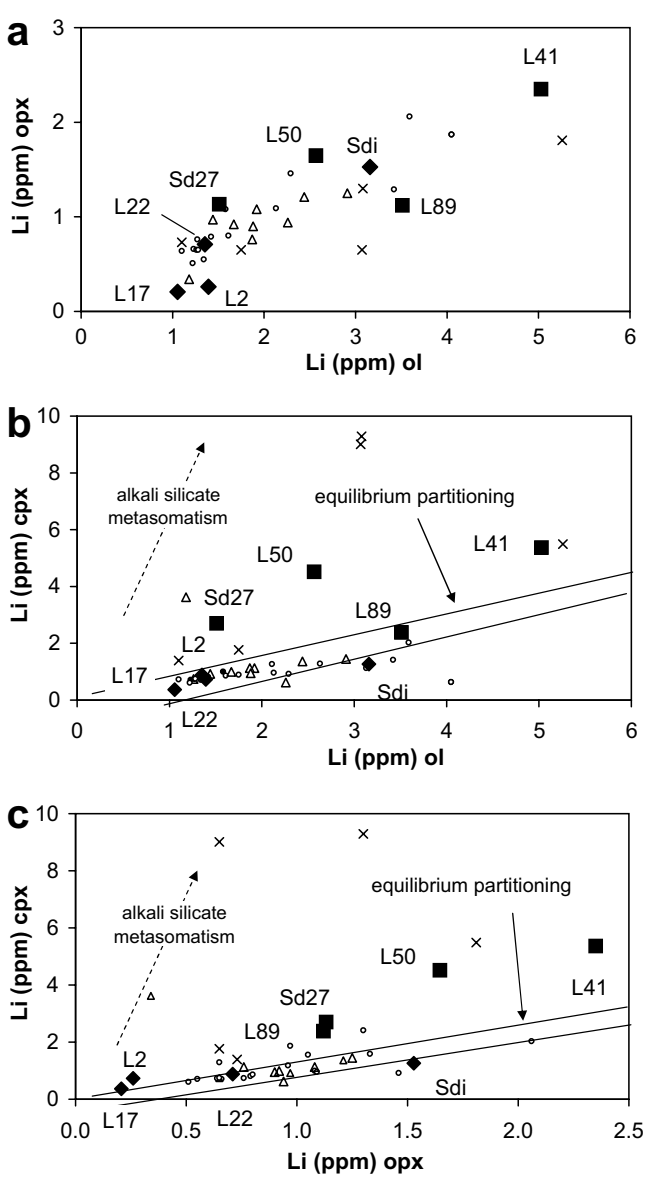

Fig. 7. Li-Li diagrams (in ppm) showing abundance relationships between the ol, opx and cpx in anhydrous samples (solid diamonds) and hydrous peridotites (solid squares) from this work. The variations of $\mathrm{Li}$ contents within individual samples have been omitted for clarity but are given in Table 2. The data are compared to peridotites from the literature. Symbols and literature data as in Fig. 6, plus anhydrous and hydrous lherzolites from Saudi Arabia (Kaliwoda and Altherr, 2003), also plotted as open circles. The solid lines indicate equilibrium partitioning deduced from equilibrated peridotites, and the arrow indicates the trend of alkali silicate metasomatism from the literature (Seitz and Woodland, 2000; Woodland et al., 2004).

Table 4

Apparent Li partition coefficients

\begin{tabular}{|c|c|c|c|c|c|c|c|}
\hline \multicolumn{4}{|c|}{ Anhydrous peridotites } & \multicolumn{4}{|c|}{ Hydrous peridotites } \\
\hline & ol/opx & $\mathrm{ol} / \mathrm{cpx}$ & opx/cpx & & ol/opx & $\mathrm{ol} / \mathrm{cpx}$ & opx/cpx \\
\hline L17 & 5.10 & 2.87 & 0.56 & $\operatorname{Sd} 27$ & 1.33 & 0.56 & 0.42 \\
\hline L2 & 5.35 & 1.91 & 0.36 & L89 & 3.14 & 1.48 & 0.47 \\
\hline L22 & 1.91 & 1.54 & 0.81 & L50 & 1.56 & 0.57 & 0.36 \\
\hline Sdi & 2.07 & 2.50 & 1.21 & L41 & 2.14 & 0.94 & 0.44 \\
\hline RL87 & 1.27 & 1.15 & 0.90 & SW00 & $1.5-4.7$ & $0.3-1.0$ & $0.1-0.5$ \\
\hline E98 & 1.46 & $1.1-1.3$ & 0.80 & KA03 & 1.74 & 1.77 & 1.01 \\
\hline SW00 & $1.4-2.4$ & $1.6-2.0$ & $0.8-1.1$ & & & & \\
\hline KA03 & 1.57 & 2.49 & 1.59 & & & & \\
\hline B98 & 1.75 & 1.30 & 0.70 & & & & \\
\hline
\end{tabular}

Literature data: natural minerals, RL87: Ryan and Langmuir (1987); E98: Eggins et al. (1998); SW00: Seitz and Woodland (2000); KA03: Kaliwoda and Altherr (2003); experimental data, $1 \mathrm{GPa}, 1320^{\circ} \mathrm{C}$, B98: Brenan et al. (1998b). 
depleted or enriched in LREE, while all the Li-rich hydrous samples have LREE-enriched patterns (Figs. 2 and 8a). This observation suggests that $\mathrm{Li}$ is transported by the same metasomatic agent that was responsible for the enrichment in LREE. This suggests that the Li carrier should be a silicate-dominated liquid. Moreover, the $\mathrm{Li}$ distribution between ol and cpx disagrees with the involvement of a carbonatitic fluid (Seitz and Woodland, 2000). No positive correlation is observed between $\mathrm{Sr}$ and $\mathrm{Li}$ in amp and cpx (Fig. 8b), although both cpx and amp from the hydrous samples are enriched in $\mathrm{Sr}$ and $\mathrm{Li}$ compared to the anhydrous samples (Fig. 8c and d). The negative correlation observed in amp (Fig. 8b) suggests a decoupling between the two elements: $\mathrm{Sr}$ may be preferentially incorporated in amp and $\mathrm{Li}$ in cpx. On the other hand, cpx and amp from the hydrous xenoliths have similar $\mathrm{Sr}$ and $\mathrm{Nd}$ isotopic ratios distinct from those of cpx from the anhydrous samples (Bouhedja et al., 2001), suggesting a strong metasomatic episode resulting in a complete re-homogenization of the $\mathrm{Sr}-\mathrm{Nd}$ isotopic composition. Therefore, the observed heterogeneous Li distribution associated with the fast Li diffusion (Richter et al., 2003) should reflect a late metasomatic event that will be discussed in the following section.

\subsection{Li isotope distribution}

As shown in Table 2, the average $\delta^{7} \mathrm{Li}(\% \circ)$ values of minerals in the anhydrous peridotites (L17, L22 and L2) range from +5 to +15 , and from +3 to +23 for individual measurements. For hydrated peridotites (Sd27, L50, L89
L41) these ranges extend from -3 to $+23 \%$ and from -10 to $+35 \%$, respectively, demonstrating the impact of hydrous metasomatism on the $\mathrm{Li}$ isotopic signature. Minerals in the layered peridotite Sdi displays a distinct range of $\delta^{7} \mathrm{Li}$ values, ranging from -5 to $+14 \%$ (average values) and from -18 to $+17 \%$ (individual measurements). In this sample, the ol and pyroxenes are not randomly distributed, and $\mathrm{Li}$ distribution may be affected by the layered texture. Therefore, Sdi values can not be directly compared with the other samples, and are excluded from the following discussion. The absence of correlation between $\mathrm{Li}$ isotopic composition and $\mathrm{Li}$ abundances in the anhydrous phases (Fig. 9a), considering either individual grains or average values for the different phases, indicate that the $\mathrm{Li}$ isotopic variation does not result from mixing between two different sources on a large scale, but rather from local processes at the inter- and intra-grain scales. In contrast, $\delta^{7} \mathrm{Li}$ and $\mathrm{Li}$ contents are negatively correlated in amp.

With the exception of two samples, the Li isotopic ratios measured in ol and opx from both anhydrous and hydrous samples lie close to the 1:1 trend (Fig. 9b) in agreement with a constant ol-opx isotopic fractionation $\left(\Delta^{7} \mathrm{Li}=\delta^{7} \mathrm{Li}^{\mathrm{ol}}-\right.$ $\left.\delta^{7} \mathrm{Li}^{\text {opx }}\right)$. The average value is $0.2 \pm 3 \%$, which, within analytical uncertainty, is the same as equilibrium ol-opx fractionation factor of $1.5 \%$ deduced by Jeffcoate et al. (2004) from anhydrous mantle xenoliths. On the contrary, the $\delta^{7} \mathrm{Li}$ of cpx and of ol do not plot on a slope 1 line (Fig. 9c), with an ol-cpx isotopic fractionation varying between 2 and 12. This indicates that cpx is out of equilibrium with both ol and opx, and suggests that the last metasomatic process is predominantly recorded by the cpx.
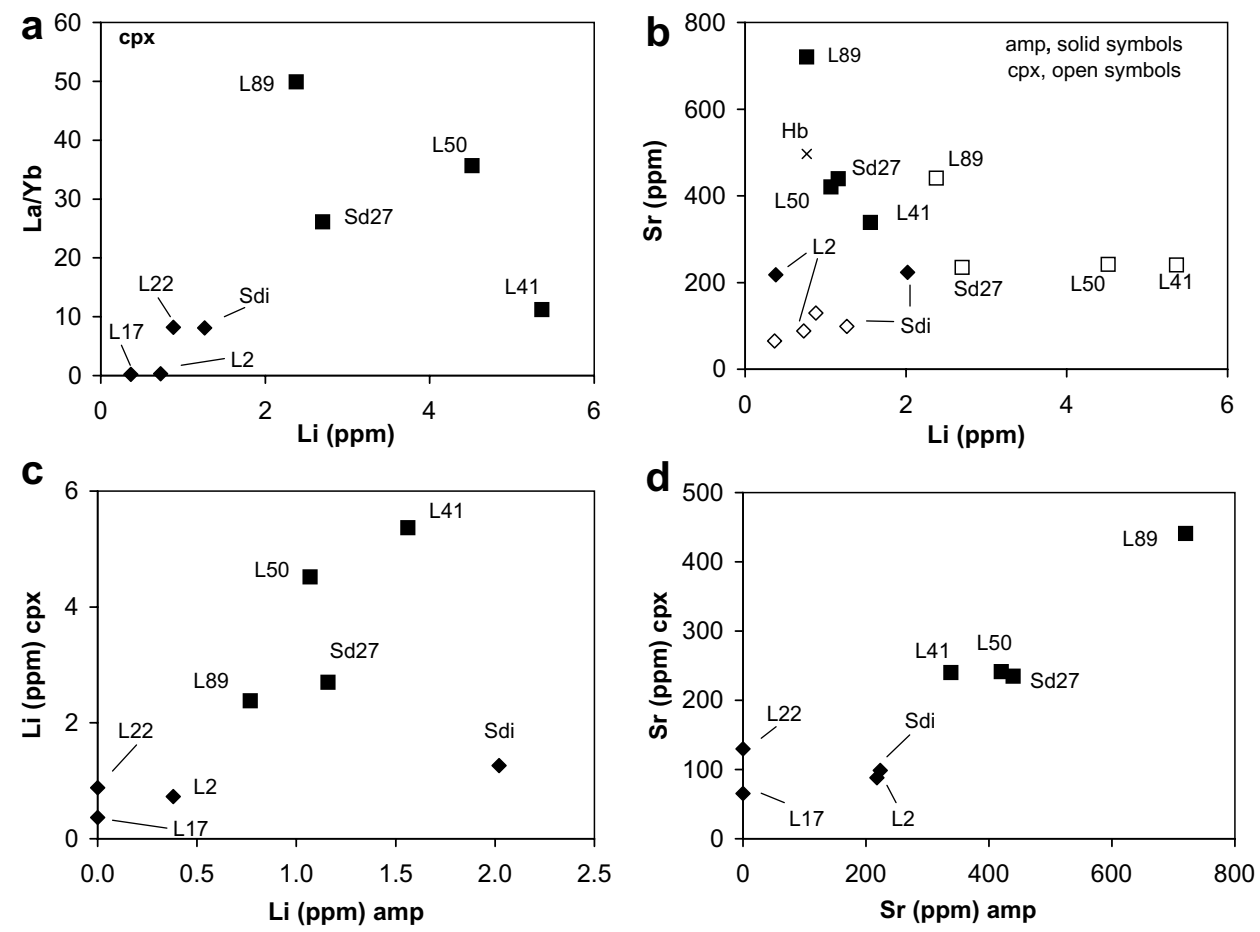

Fig. 8. Variation diagrams of fluid mobile elements in cpx and amp from anhydrous (diamonds) and hydrous (squares) peridotites: (a) La/Yb versus $\mathrm{Li}$ in cpx, (b) $\mathrm{Sr}$ versus $\mathrm{Li}$ in amp (solid symbols) and cpx (open symbols); cross = amp from the $\mathrm{Sd} 27$ hornblendite (Hb) selvage, (c) and (d) $\mathrm{Li}-\mathrm{Li}$ and $\mathrm{Sr}-\mathrm{Sr}$ diagrams in amp and cpx. 

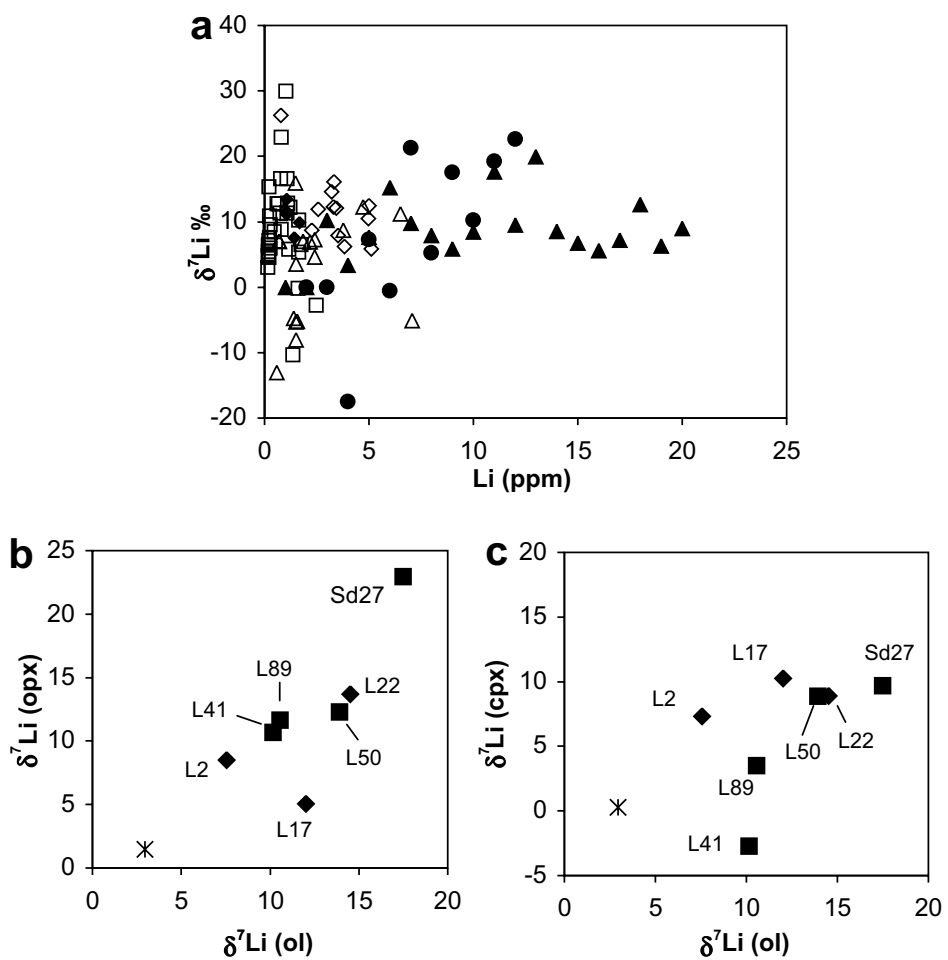

Fig. 9. (a) Variations of $\delta^{7} \mathrm{Li}(\%)$ versus Li contents (ppm) in the different anhydrous phases from the anhydrous (solid symbols) and hydrous (open symbols) peridotites: ol, diamonds, opx, squares, and cpx, triangles. Amp are represented by solid circles. Each symbol corresponds to one analytical point. Ol, opx and cpx from the hydrous samples show a large range of variation in both $\delta^{7} \mathrm{Li}$ and $\mathrm{Li}$ content compared to anhydrous samples. The Li most enriched cpx are observed in sample L41, which may be considered as the most modified rock. (b-c) Isotopic composition expressed as $\delta^{7} \mathrm{Li}(\%)$ in ol and opx (b) and cpx (c) from anhydrous (solid diamonds) and hydrous (solid squares) peridotites. The double crosses are data from the literature (Seitz et al., 2004).

\subsection{Interpretation of the isotopic variations}

Remarkable intra-grain variations in $\delta^{7} \mathrm{Li}$ were observed in the different phases from the hydrous samples (up to 18\%o), while the variations are small in the anhydrous samples $(<6 \%$ ) (Fig. 5). Similar intra-grain Li isotope heterogeneity up to $25 \%$ o has been reported in the literature (Jeffcoate et al., 2004; Bell et al., 2005). These authors favoured metasomatic processes as responsible for the variations in the $\mathrm{Li}$ isotope ratios. We measured high $\delta^{7} \mathrm{Li}$ values of up to $+15.9 \%$ in $\mathrm{cpx},+30 \%$ in opx and $+35.1 \%$ in amp from the hydrous samples, and some low negative $\delta{ }^{7} \mathrm{Li}$ values in cpx (down to $-9.7 \%$ ) from hydrous samples and in cpx (down to $-13 \%$ ) and amp (down to $-17.5 \%$ o) from sample Sdi. The low $\delta{ }^{7} \mathrm{Li}$ values reported for some eclogites and mantle xenoliths have been interpreted as resulting from the contribution of a low $\delta^{7} \mathrm{Li}$ subducted slab residue in the mantle (e.g., Tomascak et al., 1999; Zack et al., 2003; Brooker et al., 2004; Nishio et al., 2004). Bulk rock $\delta^{7} \mathrm{Li}$ values estimated by combining the measured $\delta^{7} \mathrm{Li}$ and $\mathrm{Li}$ concentrations with modal mineral abundances (Table 2) are largely positive $(+8$ to $+18 \%$ o). These values do not support the involvement of an isotopically light fluid that has interacted with an ancient subducted slab component beneath the French Massif Central. Moreover, it is likely that the extreme values recorded in some of our samples do not represent the
$\mathrm{Li}$ isotopic composition of different end-members, but are the product of $\mathrm{Li}$ isotope fractionation during metasomatism. This fractionation may be caused by high-temperature diffusion processes, as proposed by Lundstrom et al. (2005) to account for the $\mathrm{Li}$ isotopic variations in the Trinity peridotite body. Those variations occur on length scales of 10's of centimeters to 100's of meters. Similarly, the $15 \%$ variation of $\delta^{7} \mathrm{Li}$ observed in ol and cpx from the NWA 479 lunar meteorite was interpreted by Barrat et al. (2005) as resulting from a Li diffusion induced kinetic fractionation. Beck et al. (2005) proposed a similar explanation for the $15 \%$ variation of $\delta^{7} \mathrm{Li}$ observed on the cpx of the MIL 03346 nakhlite. To our knowledge, our mantle xenoliths study was the first report of $\mathrm{Li}$ isotope fractionation at the mineral grain scale, associated with a $\mathrm{Li}$ diffusion between metasomatic melt and peridotite.

On the basis of the following evidence, we argue that the $\mathrm{Li}$ distribution is not related to a post-eruption hydrothermal event, the cpx and opx equilibrated at high temperature (Table 1), and there is no petrographic evidence for late hydrous alteration. The composition of the amp both in the veins and disseminated supported their formation from a percolating silicate melt (cf. Section 4.1.3 and Table 2). The correlations between $\mathrm{Li}$ and REE elements in cpx (Fig. 8a) and between Li in cpx and amp (Fig. 8c) suggest that the carrier of the $\mathrm{Li}$ was a silicate melt. This melt is 
hydrated, at least at the end of the process, allowing formation of a small amount of amphiboles. During crystallization there is no large equilibrium $\mathrm{Li}$ isotope fractionation between the silicate melt and the minerals, so this process cannot generate the magnitude of the observed variations. Instead, we suggest that $\delta^{7} \mathrm{Li}$ variations are the result of differential diffusion of ${ }^{7} \mathrm{Li}$ and ${ }^{6} \mathrm{Li}$ in silicate melts (Richter et al., 2003). We would normally expect low $\delta{ }^{7} \mathrm{Li}$ values to be associated with the highest $\mathrm{Li}$ content, as more ${ }^{6} \mathrm{Li}$ is being pumped into the rock. However, the opposite effect is expected from the on-going melt-mineral interactions, i.e. the melt becomes isotopically heavier through diffusive loss of ${ }^{6} \mathrm{Li}$. Late crystallization of this ${ }^{7} \mathrm{Li}$ enriched melt produces high $\delta^{7} \mathrm{Li}$ overgrowths on mineral grains. As the amp crystallized directly from the metasomatising melt, it should reflect the melt's Li composition, while the compositions of the pre-existing minerals in the peridotite change by interaction with the melt. Indeed, the varying $\mathrm{Li}$ isotopic composition of the melt is supported by the large $\delta^{7} \mathrm{Li}$ variation recorded in amp from the hornblendite selvage in sample $\mathrm{Sd} 27 \mathrm{Hb}$ (Table 2). We do not observe any clear relation between Li concentration and isotopic composition in cpx, which is the main Li-enriched phase during metasomatism (Fig. 9a). This absence of correlation is probably due to the pervasive character of the metasomatism. Indeed, pervasive percolation will not impose any spatial orientation on the elemental flux in the peridotite, and, as each point may have interacted with a melt at a different stage of evolution, this process prevents the formation of any organized spatial distribution of Li isotopes. The preservation of the observed small scale $\mathrm{Li}$ isotopic composition heterogeneity implies a rapid extraction of the samples following the interaction of the melt.

The measured $\delta^{7} \mathrm{Li}$ fractionation between ol and opx suggests that these minerals have preserved their initial equilibrium $\mathrm{Li}$ isotope composition and only reflect limited interaction with the late metasomatic melt (Fig. 9b). Ol is not heavily involved in the metasomatic process as indicated by the relatively small variation in the $\mathrm{Li}$ isotope composition of ol in hydrous peridotite (Fig. 5). This is less true for the opx because the very low initial Li content of this mineral makes it susceptible to significant shifts in $\mathrm{Li}$ isotope composition. As shown on Fig. 9c, the cpx may be more affected than opx or ol by the metasomatism due to a possible diffusive $\mathrm{Li}-\mathrm{Na}$ exchange between melt and cpx. The amphibole is the only phase for which Li content and isotopic composition co-vary, showing a negative correlation (Fig. 9a). This is in accord with their formation from limited amount of silicate melt, which has strongly interacted with the peridotite. During these interactions, the melt $\mathrm{Li}$ content decreases and its $\delta^{7} \mathrm{Li}$ increases by diffusive loss of ${ }^{6} \mathrm{Li}$. The amphibole $\delta^{7} \mathrm{Li}$ values are the only direct evidence of a systematic isotopic evolution of the silicate melt during metasomatism, in the absence of diffusion patterns in the pre-existing minerals.

\section{SUMMARY AND CONCLUSIONS}

In this paper several features of $\mathrm{Li}$ behaviour during metasomatism have been highlighted:
1) Metasomatic processes increase $\mathrm{Li}$ abundances in all peridotite phases and particularly in cpx (up to $5.4 \mathrm{ppm}$ average value in hydrous metasomatised samples compared to values as low as $0.4 \mathrm{ppm}$ in cpx from anhydrous samples), while amphibole incorporates less $\mathrm{Li}(<1.4 \mathrm{ppm})$ than the other phases. The calculated whole rock $\mathrm{Li}$ contents increase from $0.8 \mathrm{ppm}$ in anhydrous peridotite to $4.0 \mathrm{ppm}$ in hydrous peridotite. In all the samples, except sample L22, the variations of $\mathrm{Li}$ isotopic composition at the intra-grain scale are up to 10 per mil for the anhydrous samples, and up to 18 per mil for the hydrous samples. There is no relation between $\mathrm{Li}$ concentrations and $\mathrm{Li}$ isotopic compositions, and, therefore, the variations do not result from a mixing between two different sources but likely result from diffusion-related $\mathrm{Li}$ isotope fractionation during metasomatism.

2) The metasomatic agent, which should be a hydrated silicate melt, percolates pervasively along grain boundaries. This mode of percolation allows strong $\mathrm{Li}$ exchanges, which results in changes in the Li content and isotopic composition of the melt as it interacts with the peridotite minerals. Therefore, no correlation is expected between the Li concentration and the isotopic composition in the metasomatised phases. The amphibole, which is a late crystallizing phase from the metasomatising melt, may record the isotopic evolution of the melt.

3) The preservation of the Li isotopes kinetic fractionation in minerals and the samples isotopic heterogeneities require that the $\mathrm{Li}$ exchange event occurs just before the extraction of the xenoliths from the mantle.

The significant Li enrichment and large isotopic fractionation during metasomatism imply that $\mathrm{Li}$ abundances and isotopes may be useful tracers of metasomatic processes. However, the possible large isotopic heterogeneities of peridotite xenoliths make difficult the identification of specific mantle sources of the metasomatic fluid.

\section{ACKNOWLEDGEMENTS}

This study was carried out during a sabbatical stay of C.W. at the CRPG, Vandoeuvre-lès-Nancy and was financially supported by the CNRS (FR32 CEPAGE and CRPG). We thank L. Reisberg (CRPG) for constructive comments and the English revision of the paper, and A. Simonetti (University of Alberta, Edmonton, Canada) for informal discussions. Critical reviews by L. Ottolini and S. Aulbach greatly improved the manuscript. We thank T. Chacko for a thorough editorial work.

\section{APPENDIX A. SUPPLEMENTARY DATA}

Supplementary data associated with this article can be found, in the online version, at doi:10.1016/j.gca.2007. 06.010 . 


\section{REFERENCES}

Barrat J. A., Chaussidon M., Bohn M., Gillet Ph., Gopel C. and Lesourd M. (2005) Lithium behavior during cooling of a dry basalt: an ion-microprobe study of the lunar meteorite Northwest Africa 479 (NWA479). Geochimica et Cosmochimica Acta 69, 5597-5609.

Beck P., Barrat J. A., Chaussidon M., Gillet Ph. and Bohn M. (2004) $\mathrm{Li}$ isotopic variations in single pyroxenes from the Northwest Africa 480 shergottite (NWA 480): a record of degassing Martian magmas? Geochimica et Cosmochimica Acta 68, 2925-2933.

Beck P., Chaussidon M., Barrat J. A., Gillet Ph. and Bohn M. (2005) An ion microprobe study of lithium isotopes behavior in nakhlites. Meteorit. Planet. Sci. 40. \#5118 (abstr.).

Bell D. R., Hervig R. L. and Buseck P. R. (2005) Li-isotopic studies of olivine in mantle xenoliths by SIMS. Lunar Planet. Sci. XXXVI. \#2178 (abstr.).

Bouhedja M., Wagner C., Reisberg L. and Deloule E. (2001) Evidence for a single metasomatic event in the lithosphere beneath the french Massif Central: mineralogical, geochemical and isotopic constraints from mantle xenoliths from the Devès province. EUG XI, EUG Journ. Conf. Abstracts 6. \#414 (abstr.).

Brenan J. M., Ryerson F. J. and Shaw E. (1998a) The role of aqueous fluids in the slab-to-mantle transfer of boron, beryllium, and lithium during subduction: Experiments and models. Geochimica et Cosmochimica Acta 62, 3337-3347.

Brenan J. M., Neroda E., Lundstrom C. C., Shaw H. F., Ryerson F. J. and Phinney D. L. (1998b) Behaviour of boron, beryllium and lithium during melting and crystallization: constraints from mineral-melt partitioning experiments. Geochimica et Cosmochimica Acta 62, 2129-2141.

Brey G. P. and Köhler T. (1990) Geothermobarometry in fourphases lherzolites. II. New thermobarometers and practical assessment of existing thermobarometers. Journal of Petrology 31, 1353-1378.

Brooker R. A., James R. H. and Blundy J. D. (2004) Trace elements and $\mathrm{Li}$ isotope systematics in Zabargad peridotites: evidence of ancient subduction processes in the Red Sea mantle. Chemical Geology 212, 179-204.

Chabiron A., Alyoshin A. P., Cuney M., Deloule E., Golubev V. N., Velitchkin V. I. and Poty B. (2001) Geochemistry of the rhyolitic magmas from the Streltsovka caldera (Transbaikalia, Russia): a melt inclusion study. Chemical Geology 175, 273-290.

Chan L. H. (2003) Variation in lithium isotopic composition in terrestrial systems. 13th Goldschmidt Conf. \#A57 (abstr.).

Chan L. H. and Edmond J. M. (1988) Variation of lithium isotope composition in the marine environment: a preliminary report. Geochimica et Cosmochimica Acta 52, 1711-1717.

Chan L. H. and Kastner M. (2000) Lithium isotopic composition of pore fluids and sediments in the Costa Rica subduction zone: implications for fluid processes and sediment contribution to the arc volcanoes. Earth and Planetary Science Letters 183, 275-290.

Chan L. H., Edmond J. M. and Gillis K. (1992) Lithium isotopic composition of submarine basalts-implications for the lithium cycle in the oceans. Earth and Planetary Science Letters 108, 151-160.

Chan L. H., Gieskes J. M., You C. F. and Edmond J. M. (1994) Lithium isotope geochemistry of sediments and hydrothermal fluids of the Guaymas basin, Gulf of California. Geochimica et Cosmochimica Acta 58, 4443-4454.

Chan L. H., Leeman W. P. and You C. F. (2002) Lithium isotopic composition of Central American volcanic arc lavas; implica- tions for modification of subarc mantle by slab-derived fluids; correction. Chemical Geology 182, 293-300.

Decitre S. E., Deloule E., Reisberg L., James R., Agrinier P. and Mével C. (2001) Behavior of $\mathrm{Li}$ and its isotopes during serpentinization of oceanic peridotites. Geochemical Geophysical Geosystem G3 2, 178.

Downes H. and Dupuy C. (1987) Textural, isotopic and REE variations in spinel peridotite xenoliths, Massif Central, France. Earth and Planetary Science Letters 82, 121-135.

Eggins S. M., Rudnick R. L. and McDonough W. F. (1998) The composition of peridotites and their minerals: a laser-ablation ICP-MS study. Earth and Planetary Science Letters 154, 53-71.

Elliott T., Jeffcoate A. and Bouman C. (2004) The terrestrial Li isotope cycle: Light-weight constraints on mantle convection. Earth and Planetary Science Letters 220, 231-245.

Flesh G. D., Anderson A. R. and Svec H. J. (1973) A secondary isotopic standard for ${ }^{7} \mathrm{Li} /{ }^{6} \mathrm{Li}$ determination. International Journal of Mass Spectrometry and Ion Processes 12, 265-272.

Frey F. A. and Prinz M. (1978) Ultramafic inclusions from San Carlos, Arizona: petrology and geochemical data bearing on their petrogenesis. Earth and Planetary Science Letters 38, $129-176$

Granet M., Wilson M. and Achauer U. (1995) Imaging a plume beneath the French Massif Central. Earth and Planetary Science Letters 136, 281-296.

Granet M., Judenherc S. and Souriau A. (2000) Des images du système lithosphère-asthénosphère sous la France et leurs implications géodynamiques : l'apport de la tomographie télésismique et de l'anisotropie sismique. Bulletin de la Societe Géologique de France 171, 149-167.

Jeffcoate A. B., Kasemann S. A. and Elliott T. (2004) High-spatial resolution isotope variation in mantle minerals. $14^{\text {th }}$ Goldschmidt Conf. \#A52 (abstr.).

Kaliwoda M. and Altherr R. (2003) Li-Be-B systematics of mantle xenoliths from Harrat Uwayrid (Saudi Arabia). $E G S-A G U$ EUG Joint Assembly, Geophys. Res. Abstract 5. \# 03745 (abstr.).

Kaliwoda M., Altherr R. and Ludwig T. (2004) Metasomatic phenomena and Li-Be-B characteristics of mantle xenoliths from Harrat Uwayrid, Saudi Arabia. $14^{\text {th }}$ Goldschmidt Conf. \#A53 (abstr.).

Lenoir X., Garrido C., Bodinier J. L. and Dautria J. M. (2000) Contrasting lithospheric mantle domains beneath the Massif Central (France) revisited by geochemistry of peridotite xenoliths. Earth and Planetary Science Letters 181, 359-375.

Lucazeau F., Vasseur G. and Bayer R. (1984) Interpretation of heat flow data in the french Massif Central. Tectonophysics 103, 99-119.

Lundstrom C. C., Chaussidon M., Hsui A. T., Kelemen P. and Zimmerman M. (2005) Observations of $\mathrm{Li}$ isotopic variations in the Trinity ophiolite: Evidence for isotopic fractionation by diffusion during mantle melting. Geochimica et Cosmochimica Acta 69, 735-751.

Matte P. (1986) Tectonics and plate tectonics model for the Variscan belt of Europe. Tectonophysics 126, 329-374.

Matte P. (1998) Continental subduction and exhumation of HP rocks In Paleozoic orogenic belts Uralides and Variscides. GFF 120, 209-222.

Maury R. C. and Varet J. (1980) Le volcanisme tertiaire et quaternaire de la France. Évolution structurale de la France. Mém. B.R.G.M. 107, 137-159.

McDonough W. F. and Sun S. S. (1995) The composition of the Earth. Chemical Geology 120, 223-253.

Mercier J. C. and Nicolas A. (1975) Texture and fabrics of upper mantle peridotites as illustrated by xenoliths from basalts. Journal of Petrology 16, 454-487. 
Mergoil J. and Boivin P. (1993) Le Velay. Son volcanisme et les formations associées. In Edition du BRGM, France, Géologie de la France, 3. pp. 3-96.

Moriguti T. and Nakamura E. (1998) Across-arc variation of Li isotopes in lavas and implications for crust/mantle recycling at subduction zones. Earth and Planetary Science Letters 163, 167-174.

Nicolas A., Lucazeau F. and Bayer R. (1987) Peridotite xenoliths in Massif Central basalts, France, Textural and geophysical evidence for asthenospheric diapirism. In Mantle xenoliths (ed. P. H. Nixon). John Wiley and Sons Ltd, Chichester, UK, pp. 563-575.

Nishio Y., Nakai S., Yamamoto J., Sumino H., Matsumoto T., Prikhod'ko V. S. and Arai S. (2004) Lithium isotopic systematics of the mantle-derived ultramafic xenoliths: implications for EM1 origin. Earth and Planetary Science Letters 217, 245-261.

Ottolini 1., Le Févre B. and Vannucci R. (2004) Direct assessment of mantle boron and lithium contents and distribution by SIMS analyses of peridotite minerals. Earth and Planetary Science Letters 228, 19-36.

Paquin J. and Altherr R. (2002) Subduction-related lithium metasomatism during exhumation of the Alpe Arami ultrahigh-pressure garnet peridotite (Central Alps, Switzerland). Contributions to Mineralogy and Petrology 143, 623-640.

Perrier G. and Ruegg J. C. (1973) Structure profonde du Massif Central français. Annales de Géophysique 29, 435-502.

Pouchou J. L. and Pichoir F. (1985) 'PAP' $(\phi-\rho-Z)$ correction procedure for improved quantitative microanalysis. In Microbeam Analysis (ed. J. T. Armstrong). San Fransisco Press, pp. 104-106.

Richter F. M., Davis A. M., DePaolo D. J. and Watson E. B. (2003) Isotope fractionation by chemical difusion between molten basalt and rhyolite. Geochimica et Cosmochimica Acta 67, 3905-3923.

Ryan J. G. and Langmuir C. H. (1987) The systematics of Li abundances in young volcanic rocks. Geochimica et Cosmochimica Acta 51, 1727-1741.

Seitz H. M. and Woodland A. B. (2000) The distribution of lithium in peridotitic and pyroxenitic mantle lithologies - an indicator of magmatic and metasomatic processes. Chemical Geology 166, $47-64$.

Seitz H. M., Brey G. P., Stachel T. and Harris J. W. (2003) Li abundances in inclusions in diamonds from the upper and lower mantle. Chemical Geology 201, 307-318.

Seitz H. M., Brey G. P., Durali S., Weyer S. and Lahaye Y. (2004) Li-isotopic signatures of peridotite xenoliths and isotopic fractionation at high temperature between olivine and pyroxenes. Chemical Geology 212, 163-167.

Stosch H. G. and Lugmair G. W. (1986) Trace element and Sr and $\mathrm{Nd}$ isotope geochemistry of peridotite xenoliths from the Eifel (West Germany) and their bearing on the evolution of the subcontinental lithosphere. Earth and Planetary Science Letters 80, 281-298.

Tomascak P. B. (2004) Developments in the understanding and application of lithium isotopes in the Earth and planetary sciences. In Johnson, C., Beard, B., Albarède, F. (Eds.), Geochemistry of Non-Traditional isotope Systems. Min. Soc. Amer. Reviews in Mineralogy and Geochemistry 55, pp. 153-195.

Tomascak P. B., Hauri E. H. and Lassiter J. C. (1999a) Lithium isotope constraints on Hawaiian plume components. AGU Fall Meeting, EOS 80. \# S354 (abstr.).
Tomascak P. B., Tera F., Helz R. T. and Walker R. J. (1999b) The absence of lithium isotope fractionation during basalt differentiation: new measurements by multicollector sector ICP-MS. Geochimica et Cosmochimica Acta 63, 907-910.

Vanucci R., Ottolini L., Bottazi P., Downes H. and Dupuy C. (1994) INAA, IDMS and SIMS comparative REE investigations of clinopyroxenes from mantle xenoliths with different textures. Chemical Geology 118, 85-108.

Wagner C., Deloule E., Chazot G. and Vilminot J. C. (1998) Elemental fractionation in composite spinel lherzolites from Massif Central (France). Constraints on possible link between cryptic and modal metasomatism. $8^{\text {th }}$ Goldschmidt Conf. \#16211622 (abstr.).

Wells P. R. A. (1977) Pyroxene thermometry in simple and complex systems. Contributions to Mineralogy and Petrology 62, 129-139.

Wilson M. and Downes H. (1991a) Mafic alkaline magmatism associated with the European Cenozoic rift system. Tectonophysics 208, 173-182.

Wilson M. and Downes H. (1991b) Tertiary-Quaternary extensionrelated magmatism in western and central Europe. Journal of Petrology 32, 811-849.

Witt G. and Seck H. A. (1989) Origin of amphibole recrystallized and porphyroclastic mantle xenoliths from the Rhenish massif: implications for the nature of mantle metasomatism. Earth and Planetary Science Letters 91, 327-340.

Woodland A. B., Seitz H. M., Altherr R., Marshall H., Olker B. and Ludwig T. (2002) Li abundances in eclogite minerals: a clue to a crustal or mantle origin ? Contributions to Mineralogy and Petrology 143, 587-601.

Woodland A. B., Seitz H. M. and Yaxley G. M. (2004) Varying behaviour of $\mathrm{Li}$ in metasomatised spinel peridotite xenoliths from Western Victoria, Australia. Lithos 75, 55-66.

Xu Y. G., Menzies M. A., Bodinier J. L., Bedini R. M., Vroon P. and Mercier J. C. (1998) Melt percolation and reaction atop a plume: evidence from the poikiloblastic peridotite xenoliths from Borée (Massif Central, France). Contributions to Mineralogy and Petrology 132, 65-84.

Zack T., Tomascak P. B., Rudnick R. L., Dalpé C. and McDonough W. F. (2003) Extremely light Li in orogenic eclogites: The role of isotope fractionation during dehydration in subducted oceanic crust. Earth and Planetary Science Letters 208, 279-290.

Zangana N., Downes H., Thirlwall M. F. and Hegner E. (1997) Relationship between deformation, equilibration temperatures, REE and radiogenic isotopes in mantle xenoliths (Ray Pic, Massif Central, France). Contributions to Mineralogy and Petrology 127, 187-203.

Zangana N., Downes H., Thirlwall M. F., Marriner G. F. and Bea F. (1999) Geochemical variation in peridotite xenoliths and their constituent clinopyroxenes from Ray Pic (French Massif Central): implications for the composition of the shallow lithospheric mantle. Chemical Geology 153, 11-35.

Zeyen H., Novak O., Landes M., Prodhel C., Driad L. and Hirn A. (1997) Refraction-sismic investigations of the northern Massif Central (France). Tectonophysics 275, 99-117.

Associate editor: Thomas Chacko 